\title{
Airborne observations of newly formed boundary layer aerosol particles under cloudy conditions
}

\author{
Barbara Altstädter ${ }^{1}$, Andreas Platis ${ }^{2}$, Michael Jähn ${ }^{3, a}$, Holger Baars ${ }^{3}$, Janine Lückerath ${ }^{4}$, Andreas Held ${ }^{4, b}$, \\ Astrid Lampert $^{1}$, Jens Bange ${ }^{2}$, Markus Hermann ${ }^{3}$, and Birgit Wehner ${ }^{3}$ \\ ${ }^{1}$ Institute of Flight Guidance, Technische Universität Braunschweig, Braunschweig, Germany \\ ${ }^{2}$ Center for Applied Geosciences, Eberhard Karls University Tübingen, Tübingen, Germany \\ ${ }^{3}$ Leibniz Institute for Tropospheric Research, Leipzig, Germany \\ ${ }^{4}$ Atmospheric Chemistry, University of Bayreuth, Bayreuth, Germany \\ ${ }^{a}$ now at: Laboratory for Air Pollution/Environmental Technology, Empa, Swiss Federal Laboratories for \\ Materials Science and Technology, Dübendorf, Switzerland \\ ${ }^{b}$ now at: Environmental Chemistry and Air Research, Technical University of Berlin, Berlin, Germany
}

Correspondence: Barbara Altstädter (b.altstaedter@tu-braunschweig.de)

Received: 6 December 2017 - Discussion started: 2 January 2018

Revised: 22 May 2018 - Accepted: 28 May 2018 - Published: 13 June 2018

\begin{abstract}
This study describes the appearance of ultrafine boundary layer aerosol particles under classical "nonfavourable" conditions at the research site of TROPOS (Leibniz Institute for Tropospheric Research). Airborne measurements of meteorological and aerosol properties of the atmospheric boundary layer (ABL) were repeatedly performed with the unmanned aerial system ALADINA (Application of Light-weight Aircraft for Detecting IN-situ Aerosol) during three seasons between October 2013 and July 2015. More than 100 measurement flights were conducted on 23 different days with a total flight duration of $53 \mathrm{~h}$. In $26 \%$ of the cases, maxima of ultrafine particles were observed close to the inversion layer at altitudes between 400 and $600 \mathrm{~m}$ and the particles were rapidly mixed vertically and mainly transported downwards during short time intervals of cloud gaps. This study focuses on two measurement days affected by low-level stratocumulus clouds, but different wind directions (NE, SW) and minimal concentrations $\left(<4.6 \mu \mathrm{g} \mathrm{m}^{-3}\right)$ of $\mathrm{SO}_{2}$, as a common indicator for precursor gases at ground. Taken from vertical profiles, the onset of clouds led to a nonlinearity of humidity that resulted in an increased turbulence at the local-scale and caused fast nucleation (e.g. Bigg, 1997; Wehner et al., 2010), but in relation to rapid dilution of surrounding air, seen in sporadic clusters of ground data, so that ultrafine particles disappeared in the verticality. The typical "banana shape" (Heintzenberg et al., 2007) of new particle
\end{abstract}

formation (NPF) and growth was not seen at ground and thus these days might not have been classified as NPF event days by pure surface studies.

\section{Introduction}

Knowledge of atmospheric aerosols is still incomplete and thus contributes to the most significant uncertainties in climate model predictions (IPCC, 2007). Depending on their optical properties, aerosols interact significantly with solar radiation and hence influence the climate directly. In particular, the formation of new particles due to nucleation by gas to particle conversion is the subject of ongoing investigations. In this context, the formation and growth rates of nucleation mode particles (ca. $1-15 \mathrm{~nm}$ in size) need a more profound understanding. By subsequent and sufficient growth, the particles can act as cloud condensation nuclei and therefore influence the Earth's climate indirectly via affecting the hydrological cycle (e.g. Kerminen et al., 2005). Particle burst events were measured worldwide using different platforms such as research stations for long-term monitoring, ships and airborne systems. Studies were performed at various altitudes from the boundary layer up into the lower stratosphere and suggested different sources and proposed several mech- 
anisms for new particle formation (NPF; e.g. Wiedensohler et al., 1996; Keil and Wendisch, 2001; Birmili et al., 2003; Kulmala et al., 2004; Hamed et al., 2010; Hamburger et al., 2011). According to these studies, NPF is likely during preconditions of low temperature; high water vapour content; low surface area of pre-existing particles, which otherwise would represent a condensation sink; presence of precursor gases and high incoming solar radiation. However, further studies presented events of NPF under non-favourable conditions, such as under the presence of clouds (e.g. Wiedensohler et al., 1997), and these investigations stress the hypothesis that nucleation might be possible under a wider range of conditions than it has been expected so far.

In particular, the small-scale vertical distribution of aerosols in the atmospheric boundary layer (ABL) needs a more profound understanding and has to be implemented in models (Boy et al., 2006). A strong connection between the vertical variability in aerosol particles and the thermodynamic structure, caused by turbulence in the continental boundary layer, has been identified by Boy et al. (2003) at SMEARII (Station for Measuring Ecosystem-Atmosphere Relations) in Hyytiälä in Finland. The study suggests a connection between NPF and high values of turbulent kinetic energy, in particular for so called "A-events" with high formation and growth rates of particles with a particle diameter of $3 \mathrm{~nm}$. Nilsson et al. (2001) considered that formation mechanisms are caused by dynamic processes in the mixed layer and entrainment zone. Bigg (1997) hypothesized that high humidity and temperature fluctuations may enhance NPF. Besides, Easter and Peters (1994) assumed favourable conditions near the inversion due to mixing processes that was afterwards demonstrated by Siebert et al. (2004) with the help of vertical profiling of the continental ABL with a balloonborne system. However, the measurements mentioned so far, except for the balloon, were conducted only in one fixed location so that the situation on a larger scale, and in particular a temporal development at different altitudes, is missing.

In this context, the use of airborne systems for atmospheric research is essential to deliver a detailed four-dimensional picture of the aerosol spatiotemporal distribution from the surface up to the free troposphere. For instance, the results of O'Dowd et al. (2009) showed the large-scale variability in the particle concentrations along air mass trajectories, and NPF and growth was observed over distances of several hundreds of kilometres. For small-scale differences in atmospheric conditions (e.g. cloud occurrence), NPF is distributed heterogeneously. The continental cloud top is favourable for NPF, as well as the cloud-free regions in between two cloud parcels (Keil and Wendisch, 2001).

The study of Wehner et al. (2015) presented the variety of nucleation mode particles around clouds over Barbados. The measurements were performed with the helicopter-borne measurement payload of TROPOS called ACTOS (Airborne Cloud Turbulence Observation System). A high frequency of occurrence of nucleation events (around $83 \%$ of all measure- ment days) was observed, whereby $50 \%$ of the events were detected on a small scale within $100 \mathrm{~m}$ in horizontal extent. In addition, the important role of the entrainment zone for NPF was confirmed by the large data set of 91 flights and the influence of clouds for favourable NPF conditions was verified. Hamburger et al. (2012) studied atmospheric aerosols with the research aircraft FAAM BAe-146 and DLR Falcon 20 and suggested nucleation events in the ABL caused by the presence of high-pressure systems and one event in the free troposphere around $8 \mathrm{~km}$ altitude due to the updraught during frontal passages. All in all, a high vertical variability in atmospheric aerosols at different locations, but in particular in the ABL, was observed; however, no detailed evolution of the vertical distribution of ABL aerosol in the same area was observed.

This publication presents results of the ALADINA unmanned aerial system (UAS) that has already been extensively used for boundary layer aerosol field studies in Melpitz (Altstädter et al., 2015; Platis et al., 2016) and was applied for turbulence measurements in west Africa (Bärfuss et al., 2018). Prior investigations of Platis et al. (2016) showed NPF in correlation with temperature and humidity fluctuations of several orders of magnitude higher than in the remaining part of the ABL, as assumed by Easter and Peters (1994). In addition, downwards transport of freshly formed particles to ground level was observed and supported by the appearance of nucleation mode particles and their subsequent growth relating to an increase in $\mathrm{SO}_{2}$ concentrations by clear sky. Due to the large data set of vertical profiles that were performed during three different seasons with ALADINA at the research site of TROPOS since 2013, a more complex role of NPF influenced by ABL processes is identified. In contrast to typical NPF events at ground by high incoming solar irradiance, other events were observed that might not have been considered by surface observations due to the sporadic appearance of ultrafine particles. The publication benefits from the comparison of ALADINA with instrumentation at ground and one model output that was applied for the MelCol (Melpitz Column) 2015 experiment, in order to get a better understanding of NPF conditions between the surface and the free troposphere.

This study is structured as follows: Sect. 2 provides an overview of the instrumentation on the UAS (Sect. 2.1) and the measurements at the TROPOS research site (Sect. 2.2). The used large Eddy simulation (LES) model is presented in Sect. 2.3. Section 3 shows the results of the newly formed boundary layer aerosol under cloudy conditions during the two measurement days, affected by the main wind directions (NE, SW). Finally, Sect. 4 concludes the presented study with the main goal to show the complexity and more frequent occurrence of NPF induced by local processes due to clouds in the ABL. 


\section{Instrumentation, model and research site}

\subsection{Aerosol and meteorological payload on the unmanned research aircraft ALADINA}

The aircraft Carolo P360 "ALADINA" (Application of Light-weight Aircraft for Detecting IN-situ Aerosol) was designed and developed for atmospheric research in order to investigate the vertical and the horizontal aerosol distribution in relation to the ABL properties. The aircraft design and the setup of the instrumentation are described in Altstädter et al. (2015). The reliability of the UAS was further supported by the results of Platis et al. (2016) and Bärfuss et al. (2018). The latter presented a detailed overview of ALADINA's flight operation, data procedure and the current payload that was re-engineered. In the following, only the instrumentation that are of interest in the current article will be introduced. The payload is equipped with aerosol instrumentation and meteorological sensors with high temporal resolution.

The total aerosol particle number concentration is derived by two condensation particle counters, CPCs (model 3007, TSI Inc., St Paul, USA), with different lower threshold diameters. In the first case study, the cut-off sizes were 5 and $10 \mathrm{~nm}$, respectively. The difference in the particle number concentrations of both CPCs $\left(N_{5}\right.$ and $\left.N_{10}\right)$, in the following referred to as $N_{5-10}$, is used for the number concentration of freshly formed particles. During the second case study, the lower threshold diameters of both CPCs were 7 and $12 \mathrm{~nm}$ $\left(N_{7}, N_{12} ; N_{7-12}\right)$, respectively. The CPCs were characterized to measure within an uncertainty of $\pm 20 \%$ with a fast response time of $1.3 \mathrm{~s}$. The laboratory results were confirmed by Bärfuss et al. (2018) during field studies in Melpitz. For data quality assurance, the UAS was placed downstream of the same aerosol inlet as used for the ground-based measurements and $N_{7-12}$ data agrees with ground data in the same particle size within the deviation of $\pm 20 \%$ during the sampling period of $1.5 \mathrm{~h}$. The CPC data were not corrected for the pressure effect, because for the pressure range of interest (900-1025 hPa) the counting efficiency of the CPC changes only minimally, i.e. less than $4 \%$ (e.g. Heintzenberg et al., 1999), which is still within the range of the overall CPC uncertainty.

In addition, an optical particle counter, OPC (model GT526, Met One Instruments Inc., Washington, USA), is installed and measures the size distribution of aerosol particles with six channels from 0.39 to $10 \mu \mathrm{m}$ (ambient) with an uncertainty of $\pm 15 \%$ and a temporal resolution of $1 \mathrm{~s}$. Here, the aerosol particle size distributions are analysed in the size windows between 390 and $700 \mathrm{~nm}$, as larger particles were not relevant in the study due to minimal appearance. In the following, the particle size distributions of the three channels refer to the aerosol particle number distribution in the size range between 390 and $500 \mathrm{~nm}\left(N_{390}\right)$, between 500 and 700 $\left(N_{500}\right)$ and between 500 to $700 \mathrm{~nm}\left(N_{700}\right)$.
The meteorological instruments are mounted at the tip of the aircraft nose next to the aerosol inlet. The sensor package consists of one five-hole probe for measuring the threedimensional wind vectors with a temporal resolution of up to $40 \mathrm{~Hz}$ and wind speed with an accuracy of $\pm 0.5 \mathrm{~m} \mathrm{~s}^{-1}$ (Wildmann et al., 2014a). The fast temperature sensors have a resolution of $10-20 \mathrm{~Hz}$ with an accuracy of $\pm 0.1 \mathrm{~K}$ (Wildmann et al., 2013). Additionally, one humidity sensor is integrated that probes the water vapour content with a response time of $1.5 \mathrm{~s}$ with $\pm 3 \%$ RH accuracy (Wildmann et al., 2014b).

\subsection{Research site Melpitz}

The research site Melpitz of TROPOS $\left(51^{\circ} 32^{\prime} \mathrm{N}, 12^{\circ} 56^{\prime} \mathrm{E}\right.$, $87 \mathrm{~m}$ a.s.l.) is located in the lowlands of Saxony, $41 \mathrm{~km} \mathrm{NE}$ of Leipzig, Germany, and surrounded by flat grass, agricultural areas and forests (e.g. Spindler et al., 2001, 2004). The flat surface and the fact that no obstacle is in the direct vicinity of the station enables its use as as airfield for a safe take-off and landing of the UAS.

Air masses arriving at Melpitz consist of up to $60 \%$ originally maritime air, due to long-distance transport by westerly winds and with predominantly enhanced concentrations of organic matter, sulphate and nitrate (Spindler et al., 2012). In the other frequent case, air masses are transported from industrial regions in eastern Europe and therefore show distinctly higher aerosol particle number concentrations in the boundary layer (e.g. Engler et al., 2007; Junkermann et al., 2016). Aerosol loads in this case are primarily characterized by anthropogenic emissions and classified as "near city background" by Putaud et al. (2004). Manninen et al. (2010) investigated NPF events at 12 different European sites including Melpitz within the framework of the EUCAARI (European Integrated project on Aerosol, Cloud, Climate, and Air Quality Interactions) project. During the intensive measurement period from March 2008 until April 2009, $57 \%$ of the available data were classified as NPF event days with a major occurrence in warm seasons and a significant maximum in May. The highest occurrence of NPF during summer was measured by Hamed et al. (2010) who focused on NPF events in connection with sulphur dioxide $\left(\mathrm{SO}_{2}\right)$ concentrations in a 10-year period for the Melpitz site from 1996 to 2006. The fraction of NPF occurrence was 30 to $50 \%$ and related to an increase in $\mathrm{SO}_{2}$ concentrations. During the earlier 1.5-year period between 1996 and 1997, 50\% of the available data was classified as nucleation with a maximum in June. However, only $30 \%$ corresponded to NPF in the period from 2003 and 2006 with the highest frequency from June to September.

Therefore, the high occurrence of NPF in spring and summer was expected during airborne observations of the presented study. A detailed description of meteorological sensors and gas analysers on site can be taken, for instance, from Hamed et al. (2010). This article describes the gas concentrations of $\mathrm{SO}_{2}$ and $\mathrm{NO}_{x}$, measured in 1-min intervals at ground. The temporal evolution of aerosol is esti- 
mated by a twin scanning mobility particle sizer, TSMPS, in the size range between 3 and $800 \mathrm{~nm}$ with a 20 min scan (Wiedensohler et al., 2012). Clouds and aerosol layers are indicated in the lowermost $3-4 \mathrm{~km}$ with backscatter signals of the ceilometer and lidar. The given range-corrected signal (see Figs. 3 and 5) is the uncalibrated attenuated backscatter coefficient that is damped by molecules and particles. For the first measurement day, ceilometer data are presented at a wavelength of $1064 \mathrm{~nm}$ (e.g. Heese et al., 2010; Wiegner and Geiß, 2012). During the second measurement day in 2015 (see Sect. 3.2), the Polly ${ }^{\mathrm{XT}}$ lidar was available and backscatter signals are shown at a wavelength of $532 \mathrm{~nm}$ (e.g. Pal et al., 1992; Althausen et al., 2009; Engelmann et al., 2016). In addition, particle fluxes and fluxes of $\mathrm{CO}_{2}$ are estimated in the second case in order to study vertical transport processes of aerosol particles and possible sources and to link between surface and UAS data.

\subsection{Large eddy simulations (LESs) with forced meso-scale model output for MelCol 2015}

ALADINA was operated in Melpitz during the field study Melpitz Column (MelCol) from 16 June until 1 July 2015. A large eddy simulation (LES) model output was run for the experiment and is used for the ABL description in order to derive a continuous data set of the vertical distribution of turbulent parameters, shown in latent heat flux $\left(w^{\prime} q^{\prime}\right)$, sensible heat flux $\left(w^{\prime} \theta^{\prime}\right)$ and turbulent kinetic energy (TKE). The model itself is described in the following.

Simulations for the MelCol 2015 measurement campaign are performed with the All Scale Atmospheric Model (ASAM; Jähn et al., 2015). It has recently been used to investigate the heat island effects on ABL modification, cloud initiation and vertical tracer mixing in the trade wind regime (Jähn et al., 2016). For the present study, LESs for selected days during the campaign were performed with respect to the present synoptic situation, including changes due to largescale advective tendencies and incoming radiation.

The computational domain is $25.2 \mathrm{~km} \times 25.2 \mathrm{~km}$ with the Melpitz field site located in the domain centre (see Fig. 1). Since the focus lies on the ABL, the model top is set to a height of $4 \mathrm{~km}$. The land use around Melpitz is characterized by mainly different forest types (farm land, shrubland, urban areas). Due to the relatively flat environment, orographic structures are not taken into account for the simulations, i.e. the model domain could be chosen as a flat surface.

The model physics is described by the prognostic TKE equation (Deardorff, 1972; Moeng and Wyngaard, 1989), by the two-moment microphysics scheme (Seifert and Beheng, 2006) with excluded ice phase in order to save computation time and by the multi-layer soil and land-use model (TERRA_ML; Doms et al., 2011) with a revised scheme for the surface layer (Jimínez et al., 2012).

The model setup is similar to the one described in Heinze et al. (2017), and it includes large-scale forcing tendencies due to advection of heat and water vapour, subsidence from the COSMO (Consortium for Small-scale Modeling, Baldauf et al., 2011) reanalysis; direct, diffuse and terrestrial radiation (1 min averages) directly measured at the field site and soil data (temperature and moisture) from the German weather service (Deutscher Wetterdienst, DWD) station "Klitzschen bei Torgau", which is located $3 \mathrm{~km}$ away from the Melpitz field site.

\section{Results and discussion}

For almost one-third of the ALADINA flights, bursts of ultrafine particles were observed under cloudy conditions close to the inversion layer. Two of the six measurement days were selected explicitly due to similar weather conditions after the passage of a low-pressure system and minimal $\mathrm{SO}_{2}$ concentrations, but different wind (NE, SW) directions that mainly influence the atmospheric structure (e.g. Engler et al., 2007; Spindler et al., 2012).

\subsection{Case I - April 2014}

In this section, NPF observations are shown on 4 April 2014, as this day is in contrast to previous investigations from Platis et al. (2016) under clear-sky conditions. Large-scale analysis revealed that air masses were transported initially from Saharan regions over eastern Europe within the last days via north-easterly winds. According to data of surface pressure systems that are publicly available by DWD, the research station was influenced by a low-pressure system and especially by the passage of a cold front that finally occluded around 18:00 UTC (-02:00 MEZ).

A typical "banana shape" (Heintzenberg et al., 2007), as a consequence of adequate condensation of precursor gases, was not observed that day. The development of the size distribution at ground level was calculated from TSMPS (see Sect. 2.2) data. The aerosol particle number concentration in the size of 10 to $800 \mathrm{~nm}$ was rather low with a mean concentration of $8 \times 10^{3} \mathrm{~cm}^{-3}$ compared to other days in springtime (e.g. Hamed et al., 2010; Platis et al., 2016). Particles from 100 to $200 \mathrm{~nm}$ in size were predominant with a mean aerosol particle number concentration of $1.0 \times 10^{4} \mathrm{~cm}^{-3}$ and evenly distributed during the whole day. Larger particles in diameter range from 200 to $800 \mathrm{~nm}$ played a minor role with a few hundred particles per cubic centimetre. Only the ultrafine particles with 10 to $100 \mathrm{~nm}$ particle diameter could be distinguished in the temporal distribution and were clustered in two events in the early morning at 02:00 and 04:15 UTC, also one further event in the afternoon at 14:00 UTC (Fig. 2a). A fourth sporadic occurrence of particles between 80 and $150 \mathrm{~nm}$ in diameter was detected at around 19:00 UTC and reached a total maximum aerosol particle number concentration of $1.5 \times 10^{4} \mathrm{~cm}^{-3}$. 
(a) Land use map Melpitz area (LES domain: $25.6 \times 25.6 \mathrm{~km}^{2}$ )

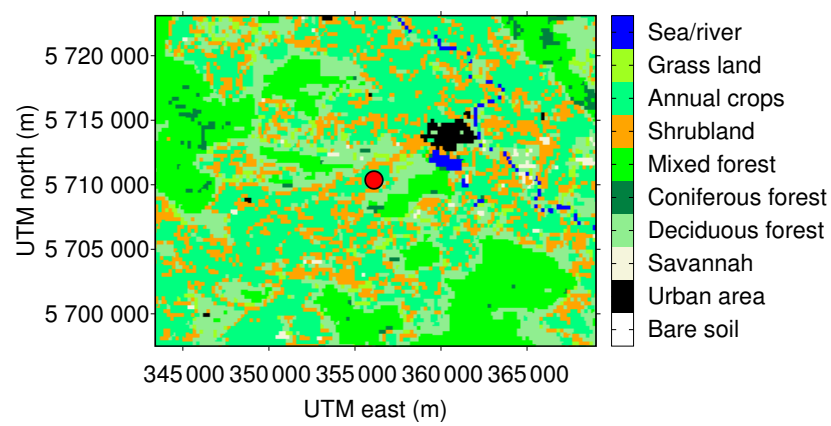

(b) Topographic map Melpitz area (LES domain: $25.6 \times 25.6 \mathrm{~km}^{2}$ )

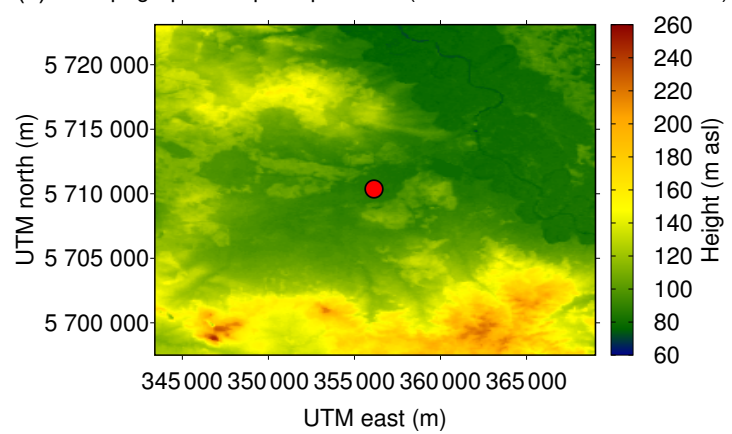

Figure 1. Land use and topography of the simulation domain considered in the All Scale Atmospheric Model (ASAM; Jähn et al., 2015) around the Melpitz field site, located in the domain centre (red dot). The large variation in vegetation on a small scale is indicated by different colours (a) and the topography ranging from 60 to $260 \mathrm{~m}$ above sea level (a.s.l.) is also indicated with the same resolution (b).

(a)

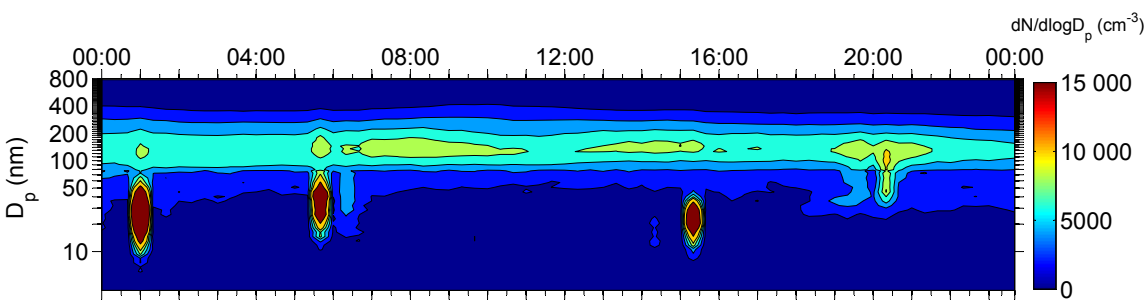

(b)

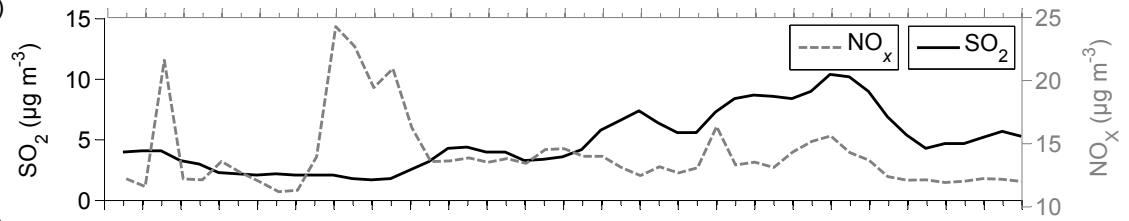

(c)

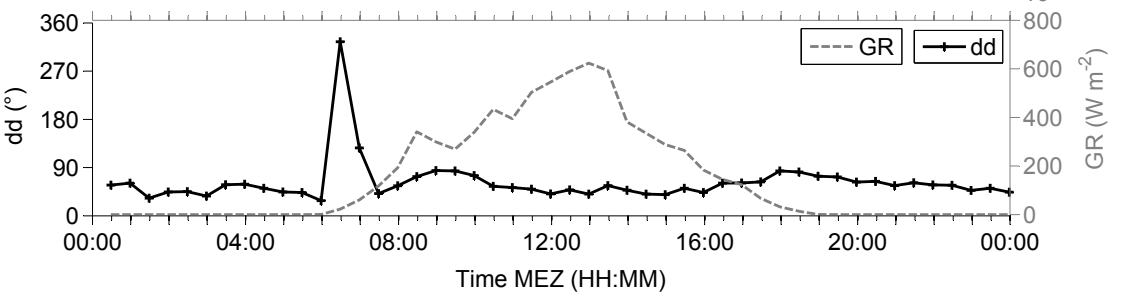

Figure 2. Ground observations in Melpitz on 4 April 2014. (a) Particle size distribution measured with TSMPS between 3 and 800 nm, (b) gas concentrations of $\mathrm{SO}_{2}$ and $\mathrm{NO}_{x}$, (c) wind direction dd and global radiation GR. More information on ground instrumentation can be taken from Wiedensohler et al. (2012) and Hamed et al. (2010).

In addition, gas concentrations of $\mathrm{SO}_{2}$ and $\mathrm{NO}_{x}$ are presented in Fig. 2b. The $\mathrm{SO}_{2}$ concentration varied between 1.4 and $4.4 \mu \mathrm{g} \mathrm{m}^{-3}$ from the early morning until 10:00 UTC. Afterwards, the concentration increased slowly to a total maximum of $11 \mu \mathrm{g} \mathrm{m}^{-3}$ at 20:40 UTC and decreased to $4.8 \mu \mathrm{g} \mathrm{m}^{-3}$ in the night. $\mathrm{NO}_{x}$ concentrations between 10.2 and $24.6 \mu \mathrm{g} \mathrm{m}^{-3}$ were measured during the day, with temporary higher concentrations in the early morning at 03:50 UTC, from 07:55 to 09:40 UTC and in the afternoon around 18:00 UTC that further coincide with the appearance of ultrafine particles observed with the TSMPS.

The temperature was low between 5.3 and $12.3^{\circ} \mathrm{C}$ and the relative humidity reached high values up to $98.1 \%$ in the early morning with a maximum at 08:25 UTC. Due to specific and only short periods of clear sky, the global radiation, GR, varied between 400 and $720 \mathrm{~W} \mathrm{~m}^{-2}$ (Fig. 2c). The wind speed was moderate in the range of 2 and $4 \mathrm{~m} \mathrm{~s}^{-1}$. The prevailing wind direction was from north-east, besides one sharp change of the wind direction, dd, from north to south-west between 08:15 and 08:55 UTC, (Fig. 2c).

\subsubsection{Cloudy conditions and heterogeneously mixed atmosphere}

A heterogeneous lower atmospheric structure was identified with the ceilometer data and the results for the lowermost $4 \mathrm{~km}$ are presented in Fig. 3. A stable nighttime ABL 


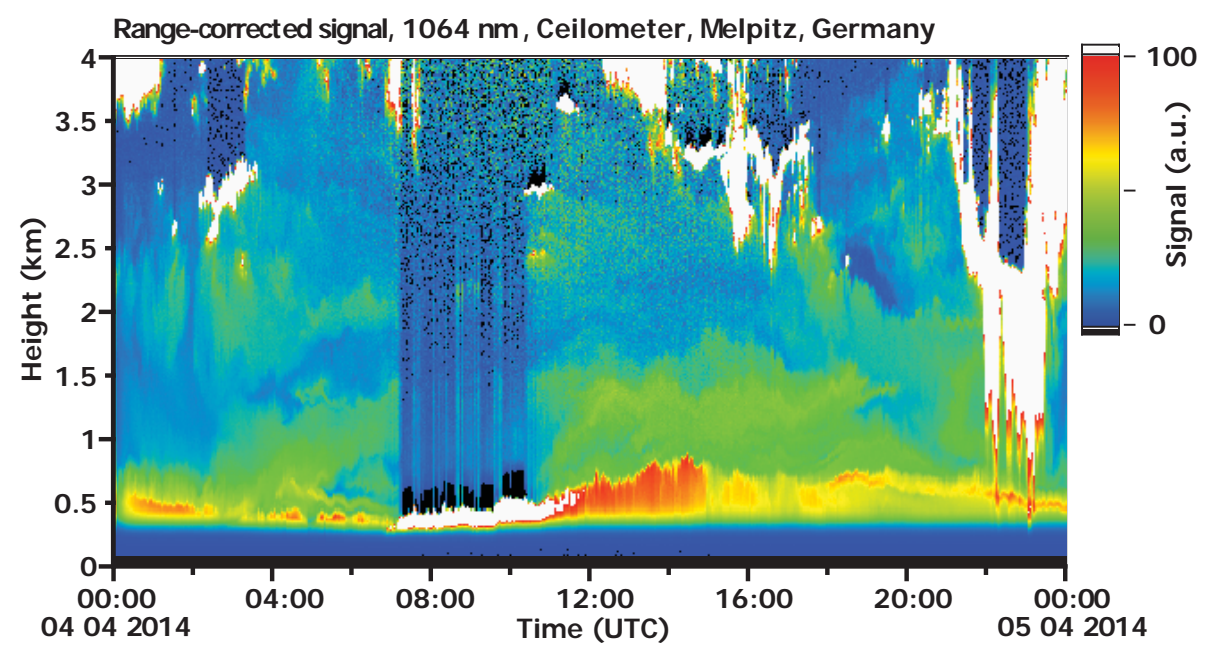

Figure 3. Backscatter signals (range corrected at the wavelength of $1064 \mathrm{~nm}$ ) of the ceilometer (e.g. Heese et al., 2010; Wiegner and Geiß, 2012) installed at Melpitz on 4 April 2014. White parts show clouds and colour scales in green up to red show the existence of atmospheric particles.

with a depth of less than $600 \mathrm{~m}$ was observed from midnight until around 07:00 UTC. Dense ABL clouds formed within this humid layer from about 07:00 to 10:00 UTC. After 10:00 UTC, the clouds dissolved and the humid convective boundary layer started growing. The maximum $\mathrm{ABL}$ depth was observed at around 14:30 UTC with an ABL top of $800 \mathrm{~m}$. Convection decayed and a residual layer (RL) remained after 16:00 UTC. Various particle (shown as green and yellow colours) and cloud (shown in white) layers were observed at different altitudes during the whole day. Partly, the lofted aerosol layers (steady existent up to $1.5 \mathrm{~km}$ ) were mixed into the ABL during the growth process. The higher aerosol layers above $1.5 \mathrm{~km}$ height were also present during the whole day but did not obviously affect the boundary layer aerosol conditions. After 20:00 UTC, precipitation was observed which did not reach the ground.

\subsubsection{NPF in the vertical distribution}

In the following, vertical profiles obtained with the UAS ALADINA are shown and the flight times are summarized and connected with weather conditions and gas concentrations of $\mathrm{SO}_{2}$ in Table 1. During Case I on 4 April, six measurement flights were performed between a maximum height of 700 and $1000 \mathrm{~m}$ a.g.l. from 06:15 until 13:58 UTC.

Figure 4 displays four vertical profiles (from left to right) of potential temperature $\theta$; water vapour mixing ratio $q$; aerosol particle number concentration $N_{5}$ (green line), $N_{10}$ (black line) and $N_{5-10}$ (grey dot), given by the two CPCs; and the aerosol particle number concentration with the three OPC channels $N_{390}$ (blue line), $N_{500}$ (red line) and $N_{700}$ (black dashed line) in the time interval at (a) 09:06, (b) 10:45, (c) 11:47 and (d) 13:50 UTC.
The first profile was taken at 09:06 UTC (Fig. 4a) and showed a strong inversion layer in the height between 420 and $550 \mathrm{~m}$ a.g.l. that was influenced by air masses of high moisture, identified by the rapid increase in $q$ from 2 to $18.5 \mathrm{~g} \mathrm{~kg}^{-1}$ within the inversion layer. $N_{5}$ decreased continuously from $6.0 \times 10^{3}$ to $4.0 \times 10^{3} \mathrm{~cm}^{-3}$ between the height of 100 and $420 \mathrm{~m}$ a.g.l. Above, a NPF event was observed, shown by $N_{5-10}=3.5 \times 10^{3} \mathrm{~cm}^{-3}$ that was strongly connected to the layer of high moisture. Above the inversion, the aerosol particle number concentration decreased to $3.0 \times 10^{3} \mathrm{~cm}^{-3}$ for the particles measured with both CPCs and remained constant to the height of $700 \mathrm{~m}$ a.g.l. In case of the OPC data, larger particles were mixed below inversion layer and significantly decreased above. At ground, less than $250 \mathrm{~cm}^{-3}$ were measured with the $390 \mathrm{~nm}$ channel, $50 \mathrm{~cm}^{-3}$ for the particle diameter of $500 \mathrm{~nm}$ and larger particles $(700 \mathrm{~nm}$ to $5 \mu \mathrm{m})$ were almost not detectable. Up to the inversion layer at $420 \mathrm{~m}$ a.g.l., the vertical distributions of $N_{390}$ and $N_{500}$ were constant and decreased rapidly along with the maximum of $N_{5-10}$. Between the altitude of 470 and $700 \mathrm{~m}$ a.g.l., the aerosol particle number concentration of $N_{390}$ and $N_{500}$ were constant with low values of $N_{390}=110$ and $N_{500}=20 \mathrm{~cm}^{-3}$. At 10:45 UTC (Fig. 4b), the inversion layer was lifted up to a height between 500 and $700 \mathrm{~m}$ a.g.l. and still connected to the layer of high moisture. Here, only data from the CPC with the lower cut-off size of $5 \mathrm{~nm}$ were available. The CPC detected particles up to $0.8 \times 10^{4} \mathrm{~cm}^{-3}$ between ground level and the capping inversion at the height of $450 \mathrm{~m}$ a.g.l. Hereafter, the amount of $N_{5}$ increased steadily to $3.8 \times 10^{4} \mathrm{~cm}^{-3}$ at the altitude around $700 \mathrm{~m}$ a.g.l. with two distinct layers of particles. Below the inversion, ultrafine particles were evenly dispersed within the ABL, but above the inversion a heterogeneous distribution was observed up to the height of 
Table 1. Airborne measurements performed with the UAS ALADINA during Case I on 4 April 2014. The flight time of ALADINA between take-off and landing and the maximum altitude of flights are shown. In addition, prevailing conditions of clouds, $\mathrm{SO}_{2}$ gas concentration, pressure at the surface $p_{0}$ and temperature $T_{1 \mathrm{~m}}$ from mast in $1 \mathrm{~m}$ height are presented in relation to the corresponding flights.

\begin{tabular}{lrrlrrr}
\hline Flight & $\begin{array}{r}\text { Flight time } \\
(\mathrm{UTC})\end{array}$ & $\begin{array}{r}\text { Max. height } \\
(\mathrm{m} \text { a.g.1. })\end{array}$ & Sky conditions & $\begin{array}{r}\mathrm{SO}_{2} \\
\left(\mu \mathrm{g} \mathrm{m}^{-3}\right)\end{array}$ & $\begin{array}{r}p_{0} \\
(\mathrm{hPa})\end{array}$ & $\begin{array}{r}T_{1 \mathrm{~m}} \\
\left({ }^{\circ} \mathrm{C}\right)\end{array}$ \\
\hline 1 & $06: 15-06: 50$ & 950 & stratocumulus & $1.7-2.4$ & 998 & $7.7-8.8$ \\
2 & $07: 50-08: 17$ & 700 & ABL clouds & $1.1-2.2$ & 999 & $5.3-6.1$ \\
3 & $08: 55-09: 30$ & 750 & ABL clouds & $1.9-2.9$ & 999 & $7.0-9.1$ \\
4 & $10: 41-11: 28$ & 1000 & ABL clouds & $3.7-4.6$ & 1000 & $10.8-11.3$ \\
5 & $11: 45-12: 27$ & 950 & ABL clouds-stratocumulus & $2.7-4.4$ & 1000 & $10.8-12.1$ \\
6 & $13: 20-13: 58$ & 950 & stratocumulus & $3.6-5.0$ & 1001 & $11.8-12.3$ \\
\hline
\end{tabular}
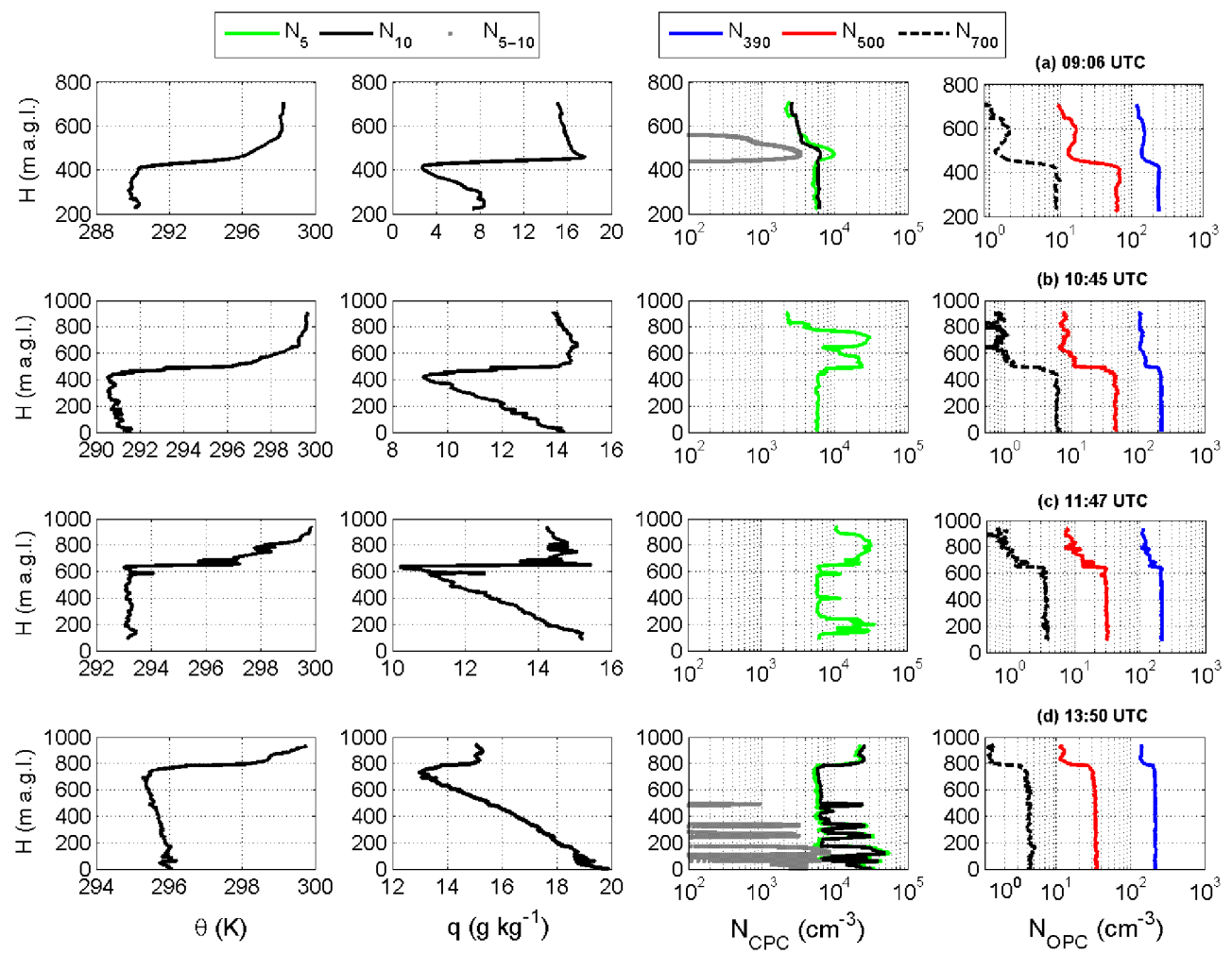

Figure 4. Vertical profiles of potential temperature $\theta$; water vapour mixing ratio $q$; aerosol particle number concentration of ultrafine particles measured with two CPCs in the particle diameter above $5 \mathrm{~nm}$ (green line), above $10 \mathrm{~nm}$ (black line) and $N_{5-10}$ (grey dot). Total aerosol particle number concentration measured with the OPC in the size above $390 \mathrm{~nm}$ (blue line), $500 \mathrm{~nm}$ (red line) and $700 \mathrm{~nm}$ (dashed black line) are also shown. All data were measured with ALADINA at (a) 09:06, (b) 10:45, (c) 11:47 and (d) 13:50 UTC on 4 April 2014.

$800 \mathrm{~m}$ a.g.l., where the aerosol particle number concentration decreased rapidly to a minimum of $N_{5}=0.5 \times 10^{4} \mathrm{~cm}^{-3}$. At the same time, $N_{390}$ was also evenly distributed below the inversion and reached values around $220 \mathrm{~cm}^{-3}$. Within the height of 450 and $500 \mathrm{~m}$ a.g.l., the concentration decreased to $N_{390}=130 \mathrm{~cm}^{-3}$. Between 500 and $950 \mathrm{ma.g} .1$. in altitude, the aerosol particle number concentration varied between 110 and $120 \mathrm{~cm}^{-3}$. The same distribution occurred for particles in the diameter size of $500 \mathrm{~nm}$, but with minimal concentrations. The next vertical profile was taken at 11:47 UTC (Fig. 4c). A high increase in $N_{5}$ with a maximum aerosol particle number concentration of $3.8 \times 10^{4} \mathrm{~cm}^{-3}$ was observed in the height between 150 and $250 \mathrm{~m}$ a.g.l. A second layer with enhanced values of $N_{5}$ was detected above the inversion layer in the heights of 630 and $950 \mathrm{~m}$ a.g.l. with a maximum of $3.4 \times 10^{4} \mathrm{~cm}^{-3}$. The results of the OPC were almost the same as $1 \mathrm{~h}$ before and significantly affected by the inversion layer. Later, at 13:50 UTC (Fig. 4d), the aerosol particle number concentration was detected with both CPCs again. From ground level up to the inversion at $800 \mathrm{~m}$ a.g.l., the maximum of $N_{5-10}=0.5 \times 10^{4} \mathrm{~cm}^{-3}$ appeared. Above 
800 m a.g.l., the decline of $N_{390}$ and $N_{500}$ was still present and linked to the increase in ultrafine particles.

The overall observation was the occurrence of NPF connected to a layer of high moisture close to the inversion depending on the decline of particles $>390 \mathrm{~nm}$ in size, as an indicator for the decreasing condensation sink that might have favoured the particle formation process. Strong gradients in the vertical distribution of the humidity intensified turbulence and caused fast nucleation, as it was proposed by (e.g. Bigg, 1997; Wehner et al., 2010). Although, the main wind direction was from NE, the authors do not consider any emission via long-range transport by a combustion source in this case, as it was stated by Junkermann et al. (2016). If there would be a source of ultrafine particles upwind of the site, the particles would grow fast ( $>50 \mathrm{~nm}$ in size) during the transport. Furthermore, if the ultrafine particles observed in Melpitz would have been formed far away, they would not appear as single bursts. Such small structures with sharp gradients to the environment would dilute very quickly within the time span of minutes at maximum. However, local sources can not be excluded, as $\mathrm{NO}_{x}$ increased during sporadic appearances of particles $<50 \mathrm{~nm}$ at ground. However, the authors suggest that these particles were produced elsewhere and transported to the site.

\subsection{Case II - June 2015}

The second case presents observations from 21 June 2015 . ALADINA flights were performed as part of the MelCol 2015 experiment so that additional instrumentation was available at the site. Within the last five days starting on 16 June 2015, retrieved back-trajectories showed air masses originated over the Atlantic, so that a low aerosol load was expected. The research site was influenced by a low-pressure system leading to a mixed structure of stratocumulus clouds in the height of $500-2500 \mathrm{~m}$. The cloud coverage can be further taken from the Polly ${ }^{\mathrm{XT}}$ lidar (e.g. Althausen et al., 2009; Engelmann et al., 2016; Baars et al., 2017) data from 06:00 until 18:00 UTC (Fig. 5).

An overview of the performed measurement flights with ALADINA in connection with weather conditions and gas concentrations of $\mathrm{SO}_{2}$ (between 0.8 and $3.7 \mu \mathrm{g} \mathrm{m}^{-3}$ ) can be found in Table 2. In this case, seven flights were performed between 08:00 and 15:32 UTC with a total maximum height of $1200 \mathrm{~m}$ a.g.l. The temperature at $1 \mathrm{~m}$ height was in the range of 9.4 and $18.3^{\circ} \mathrm{C}$ during the day. The wind speed was weak between 0 and $3.7 \mathrm{~m} \mathrm{~s}^{-1}$ coming from SW, so that nucleation cannot be expected due to clean air masses, according to the results of Junkermann et al. (2016).

The diurnal evolution of particle number size distribution measured by TSMPS at ground is displayed in Fig. 6a. The aerosol load was constantly dispersed until 07:20 UTC with the highest number concentrations of $5.0 \times 10^{4} \mathrm{~cm}^{-3}$ in the size between 30 and $50 \mathrm{~nm}$. Particles belonging to the accumulation mode were insignificant on this day and reached values of only a few 100 particles $\mathrm{cm}^{-3}$. At 07:50 UTC, a sporadic NPF event was observed with a maximum aerosol particle number concentration of $1.5 \times 10^{5} \mathrm{~cm}^{-3}$ in the size between 3 and $10 \mathrm{~nm}$. At the same time, a significant decline of accumulation mode particles was measured. However, the NPF event stopped within $20 \mathrm{~min}$ and the aerosol particle number concentration of particles larger than $20 \mathrm{~nm}$ increased, although the concentrations were still low during the day. In the following, five events with a significant increase in the aerosol particle number concentration in the diameter size between 7 and $20 \mathrm{~nm}$ were temporarily clustered at 10:10, 11:50, 13:20, 14:50 and 16:10 UTC. The sporadic appearances of small particles were ongoing with a decrease in the aerosol particle number concentration of particles in the diameter of $30-50 \mathrm{~nm}$. Figure $6 \mathrm{~b}$ displays the diurnal cycle of $\mathrm{CO}_{2}$ fluxes, $w^{\prime} \mathrm{CO}_{2}{ }^{\prime}$, estimated with the eddy covariance (EC) station that was deployed during the analysed measurement day. During non-events, the fluxes were positive and reached a maximum of $0.2 \mathrm{mg} \mathrm{kg}^{-1} \mathrm{~m} \mathrm{~s}^{-1}$ in the night at 01:30 UTC. At 05:00 UTC, negative values of $w^{\prime} \mathrm{CO}_{2}^{\prime}$ occurred with a maximum of $-0.2 \mathrm{mg} \mathrm{kg}^{-1} \mathrm{~m} \mathrm{~s}^{-1}$ at 08:40 UTC, that was at the same time with the sporadic appearance of small particles. In order to show a direct dependence of water vapour on nucleation, Fig. $6 \mathrm{c}$ depicts the liquid water path, LWP, calculated from the LES model during the measurement period. Highest values of up to $10 \mathrm{~kg} \mathrm{~m}^{-2}$ indicated the existence of dense ABL clouds and nucleation occurred in a short time period by mean LWP values of $3.5 \mathrm{~kg} \mathrm{~m}^{-2}$. Gas concentrations of $\mathrm{SO}_{2}$ were low $\left(<3.7 \mu \mathrm{g} \mathrm{m}^{-3}\right.$ ) during measurement flights (see Fig. 6d). The maximum occurred in relation to the occurrence of ultrafine particles in the afternoon at around 14:50 UTC. In contrast to the previous measurement day, the concentration of $\mathrm{NO}_{x}$ was minimal between 2.5 and $10.1 \mathrm{\mu g} \mathrm{m}^{-3}$ and did not coincide with the sporadic appearance of ultrafine particles in the TSMPS data.

A similar observation of clustered NPF during cloudy conditions and westerly wind in Melpitz was recently presented in the study of Größ et al. (2018). An insufficient particle growth rate was significantly connected to fluctuations of hydroxyl radicals and $\mathrm{H}_{2} \mathrm{SO}_{4}$ (shown in the so called Case 4) that were steadily suppressed by clouds in contrast to a high increase in $\mathrm{H}_{2} \mathrm{SO}_{4}$ during clear-sky events. The authors suggested local processes and steady influencing sources as the cause for this formation behaviour. In order to understand possible local processes in the current work, additional estimations of particle fluxes will be considered for the day. Figure 7 displays particle fluxes taken from the EC station that was deployed several metres away from the UAS operation and ground monitoring. Short lifetime and quick fluctuations of emission (shown in blue, positive particle flux) and deposition (shown in red, negative particle flux) were prevailing during the day. Significant deposition occurred with a maximal particle flux of $-26 \times 10^{6} \mathrm{~m}^{-2} \mathrm{~s}^{-1}$ at 12:30 UTC, taken from the $30 \mathrm{~min}$ averaging, that is in relation to the occur- 


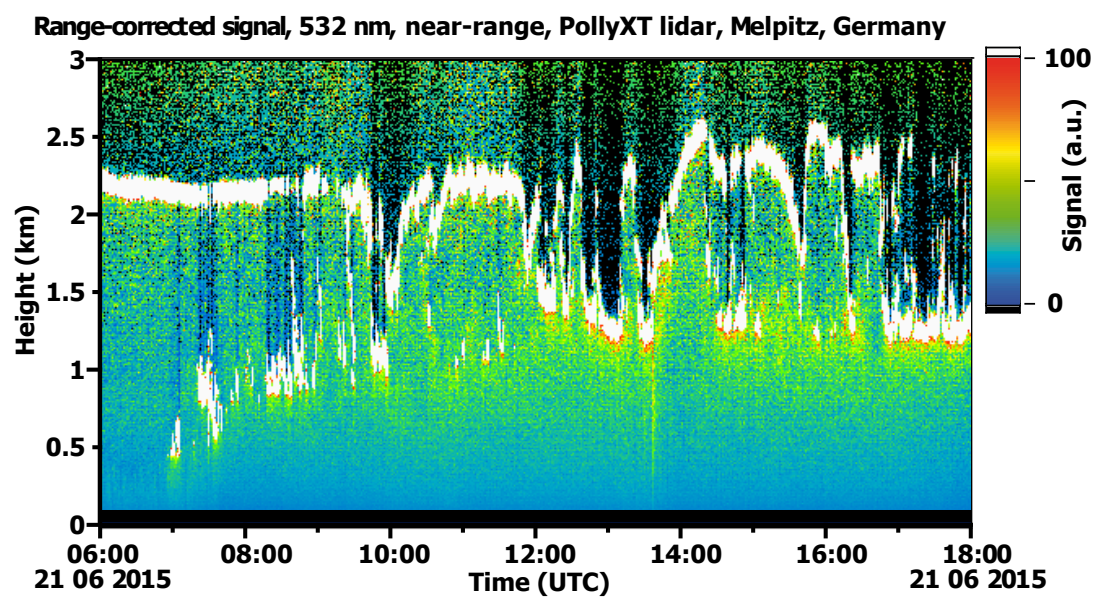

Figure 5. Backscatter signals (range corrected at the wavelength of $532 \mathrm{~nm}$ ) of Polly XT lidar installed at Melpitz on 21 June 2015 . White parts show clouds and colour scales in green up to red show the existence of atmospheric particles. More details of the lidar can be taken from Engelmann et al. (2016).

Table 2. Performed airborne measurements with the UAS ALADINA during MelCol experiment Case II on 21 June 2015 . The flight time of ALADINA between take-off and landing and the maximum altitude of flights. In addition, prevailing conditions of clouds, $\mathrm{SO}_{2}$ gas concentration, pressure at surface $p_{0}$ and temperature $T_{1 \mathrm{~m}}$ from mast in $1 \mathrm{~m}$ height are presented in relation to corresponding flight time series.

\begin{tabular}{lrrlrrr}
\hline Flight & $\begin{array}{r}\text { Flight time } \\
(\mathrm{UTC})\end{array}$ & $\begin{array}{r}\text { Max. height } \\
(\mathrm{m} \text { a.g.l. })\end{array}$ & Sky conditions & $\begin{array}{r}\mathrm{SO}_{2} \\
\left(\mu \mathrm{g} \mathrm{m}^{-3}\right)\end{array}$ & $\begin{array}{r}p_{0} \\
(\mathrm{hPa})\end{array}$ & $\begin{array}{r}T_{1 \mathrm{~m}} \\
\left({ }^{\circ} \mathrm{C}\right)\end{array}$ \\
\hline 1 & $08: 00-08: 35$ & 950 & ABL clouds-stratocumulus & $1.2-1.6$ & 1007 & $14.8-15.9$ \\
2 & $08: 46-09: 15$ & 950 & stratocumulus & $0.9-1.2$ & 1007 & $15.4-17.4$ \\
3 & $09: 28-10: 01$ & 950 & stratocumulus & $0.8-0.9$ & 1007 & $14.7-17.4$ \\
4 & $12: 03-12: 38$ & 1100 & stratocumulus & $1.2-1.5$ & 1007 & $15.7-17.1$ \\
5 & $12: 51-13: 15$ & 1200 & stratocumulus & $1.2-1.3$ & 1006 & $15.7-16.3$ \\
6 & $13: 51-14: 23$ & 1200 & stratocumulus & $1.4-1.5$ & 1005 & $15.6-18.3$ \\
7 & $14: 57-15: 32$ & 1200 & stratocumulus & $1.4-3.7$ & 1005 & $16.9-17.7$ \\
\hline
\end{tabular}

rence of ultrafine particles and the break of ABL clouds. Deposition with a maximum of $-75 \times 10^{6} \mathrm{~m}^{-2} \mathrm{~s}^{-1}$ was shown by Buzorius et al. (2001) during a clear nucleation event with particle growth rate, measured with cut-off sizes of 7 and $14 \mathrm{~nm}$. Moreover, the study observed high frequencies (87\%) of downward fluxes during nucleation events that might lead to the assumption of local sources from upper layers so that not only emissions near ground level should be considered. Possible causes for NPF in the ABL, initiated by turbulence were previously suggested by Nilsson et al. (2001) as well.

Again, no typical shape of NPF with a high and steadily increasing growth rate was observed during this day with dense cloud coverage of stratocumulus; however, nucleation appeared to be sporadically affected by local processes of clouds.

\subsubsection{ABL properties during the NPF event}

ABL characteristics were not available from the UAS and were estimated with the LES model output (Sect. 2.3) in a vertical resolution of $50 \mathrm{~m}$, beginning at the altitude of $25 \mathrm{~m}$. The top of the ABL height varied between 900 and $1200 \mathrm{~m}$ in the period of 06:00 until 16:00 UTC (Fig. 8). The water vapour mixing ratio $q$ reached maxima between heights of 950 and $1210 \mathrm{~m}$ near the inversion layer. The total maximum of $q=18.5 \mathrm{~g} \mathrm{~kg}^{-1}$ was estimated in the afternoon in the $1 \mathrm{~h}$ time interval between 14:00 and 15:00 UTC in the height of $1200 \mathrm{~m}$. The vertical profile of turbulent kinetic energy, TKE, from the surface up to $1500 \mathrm{~m}$ showed a strong connection with the structure of the ABL with highest rates between 0.6 and $1.15 \mathrm{~m}^{2} \mathrm{~s}^{-2}$. In the lowermost $50 \mathrm{~m}$, TKE reached its highest value and a total maximum of $1.18 \mathrm{~m}^{2} \mathrm{~s}^{-2}$ between 06:00 and 07:00 UTC. At 150m, TKE decreased compared to the surface inversion and was stable between 1200 and $1500 \mathrm{~m}$. Close to the transition zone into the free troposphere, TKE was negligible. All in all, the LES output showed a capped inversion with high moisture and moderate wind speed in the lowermost $200 \mathrm{~m}$ and simultaneously the highest value of TKE. 


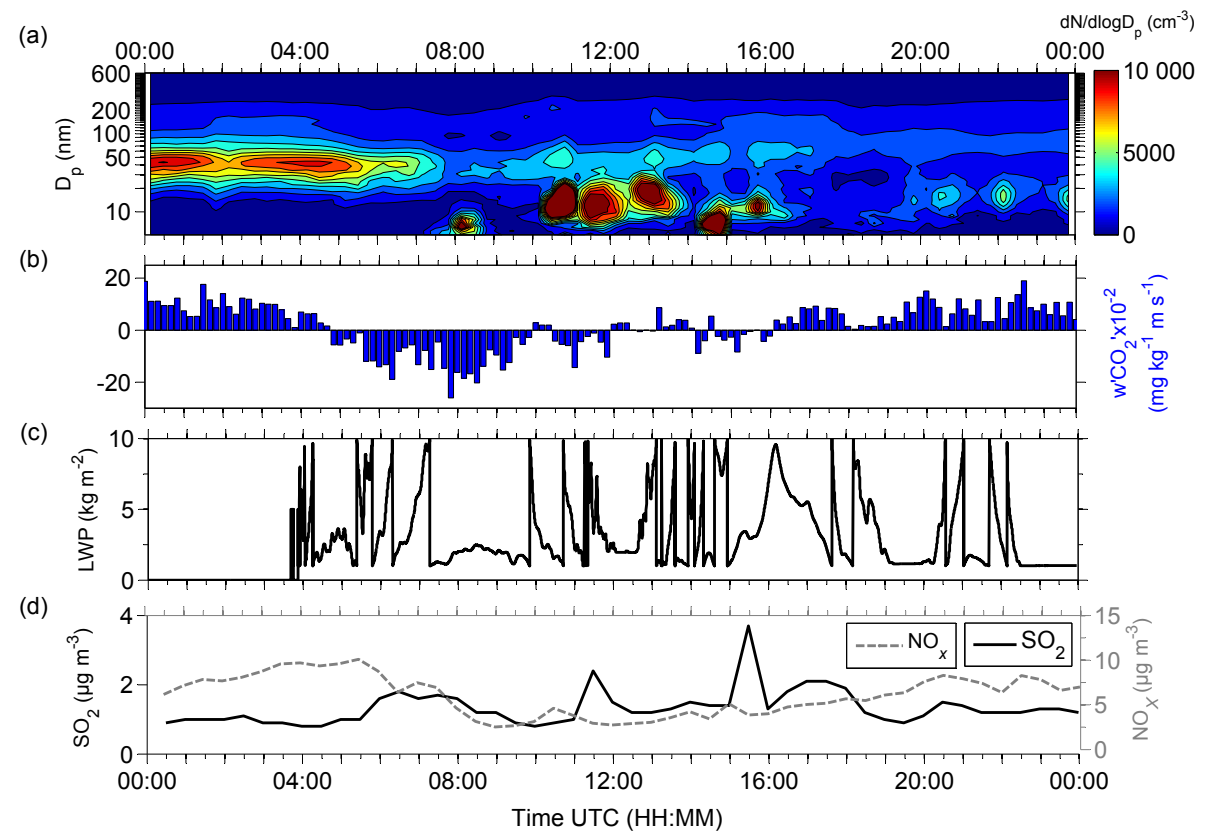

Figure 6. (a) Particle size distribution measured with TSMPS, (b) fluxes of $\mathrm{CO}_{2}$, (c) liquid water path, LWP and (d) gas concentrations of $\mathrm{SO}_{2}$ and $\mathrm{NO}_{x}$ during the MelCol experiment on 21 June 2015. The homogeneous aerosol load was affected by ABL growth after 07:30 UTC and six sporadic formation events (seen in red dots in the size range of 10 to $20 \mathrm{~nm}$ ) were indicated during daytime between 08:10 and 16:10 UTC under cloudy conditions and south-westerly wind.

\subsubsection{Vertical mixing of NPF}

Two of the six sporadic nucleation events (see Fig. 6) were observed with the UAS ALADINA on 21 June 2015. The first case corresponds to the NPF event at around 08:00 UTC and the results are shown in Fig. 9. The vertical profile of sensible heat flux $w^{\prime} \theta^{\prime}$ and latent heat flux $w^{\prime} q^{\prime}$ were estimated with the LES model and presented for a $1 \mathrm{~h}$ interval between 08:00 and 09:00 UTC from the surface up to $1000 \mathrm{~m}$ a.g.l. in altitude. During this period, three vertical profiles of the UAS were performed at 08:13 (solid line), 08:20 (dotted line) and 08:26 UTC (dashed line) in the height between 100 and $950 \mathrm{~m}$ a.g.l. Note that during this study, the lower cut-off sizes of the two CPCs were 7 and $12 \mathrm{~nm}$ in particle diameter, respectively (see Sect. 2.1). At 08:13 UTC (black line), the vertical profile of $N_{7-12}$ showed a high variance: at $100 \mathrm{ma}$ a.g. $N_{7-12}$ was $8 \times 10^{4} \mathrm{~cm}^{-3}$ and decreased to $3 \times 10^{4} \mathrm{~cm}^{-3}$ at the height of $390 \mathrm{~m} \mathrm{a.g.l}$. Above, a significant maximum of $16 \times 10^{4} \mathrm{~cm}^{-3}$ was measured at the height of $500 \mathrm{~m}$ a.g.l. and existed up to $790 \mathrm{~m}$ a.g.l. Between the heights of 800 and 950 ma.g.l, $N_{7-12}$ decreased to $10 \times 10^{4} \mathrm{~cm}^{-3}$ in connection to a layer of maximum $w^{\prime} q^{\prime}=25 \mathrm{~g} \mathrm{~kg}^{-1} \mathrm{~m} \mathrm{~s}^{-1}$ and negative values of $w^{\prime} \theta^{\prime}$ from -2 to $-18 \times 10^{-3} \mathrm{~K} \mathrm{~m} \mathrm{~s}^{-1}$. Only $17 \mathrm{~min}$ later, at $08: 20 \mathrm{UTC}$, the lifted layer of enhanced aerosol concentration above $500 \mathrm{~m}$ a.g.l. was not observed anymore. However, below the altitude of $410 \mathrm{~m}$ a.g.l., the vertical distribution of $N_{7-12}$ was as before. At 08:26UTC, the aerosol particle number con- centration of $N_{7-12}$ was homogeneously mixed in the vertical distribution with a mean aerosol number concentration of $2.5 \times 10^{4} \mathrm{~cm}^{-3}$.

For comparison, TSMPS data were estimated for the same size of $N_{7-12}$. At 07:40 UTC, $N_{7-12}=2 \times 10^{4} \mathrm{~cm}^{-3}$ was measured at surface, before nucleation started. During the first flight of ALADINA, the maximum of $N_{7-12}$ was $9 \times 10^{4} \mathrm{~cm}^{-3}$ at ground. Further, $N_{7-12}$ decreased to $3 \times 10^{4} \mathrm{~cm}^{-3}$ at 08:30 UTC and $1 \times 10^{4} \mathrm{~cm}^{-3}$ at 08:50 UTC. ALADINA observations in the lowermost $100 \mathrm{~m}$ a.g.l. were consistent with TSMPS data at ground. Thus, ground observations calculated by integration of a size scan over $20 \mathrm{~min}$ can not reproduce the significant spread of $N_{7-12}$ within the $\mathrm{ABL}$, but are still consistent with profiling data.

Figure 10 displays the same parameters as given in Fig. 9 for the time interval between 14:00 and 15:00 UTC, corresponding to the fifth sporadic nucleation event seen in TSMPS observations on 21 June 2015. At 14:16 UTC, the vertical profile of ALADINA (solid line) showed a homogeneous distribution of $N_{7-12}$ with a mean aerosol particle number concentration of $3.5 \times 10^{4} \mathrm{~cm}^{-3}$. The second profile was measured at 14:57 UTC (dotted line) with a significant increase in $N_{7-12}=1.8 \times 10^{5} \mathrm{~cm}^{-3}$ at ground and decreased rapidly in the vertical pattern between the height of 160 and $1100 \mathrm{~m}$. The region corresponds to a maximum of sensible heat flux of $56 \times 10^{-3} \mathrm{~K} \mathrm{~m} \mathrm{~s}^{-1}$. The third vertical profile was taken at 15:06 UTC (dashed line) and $N_{7-12}$ was mixed in the vertical distribution by a mean aerosol number concen- 

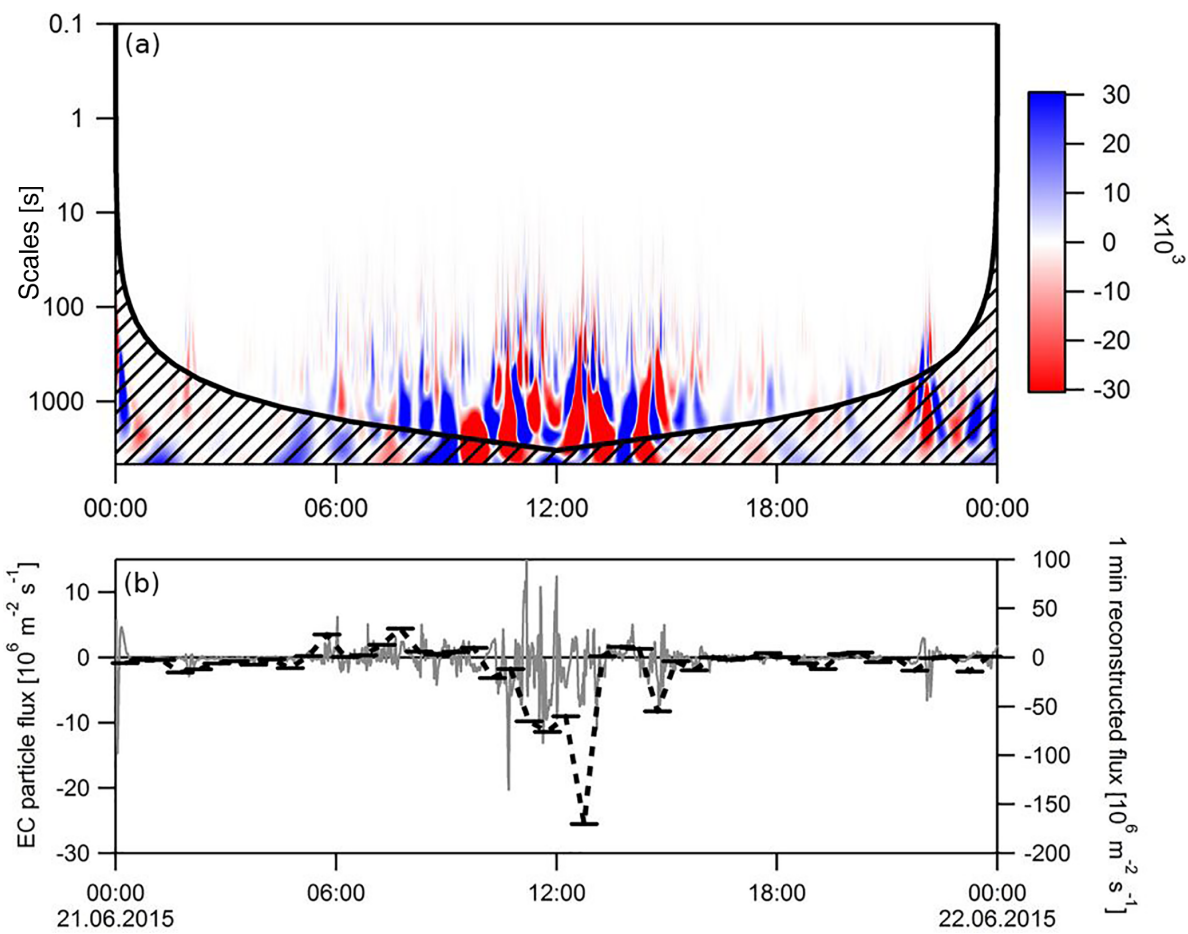

Figure 7. Cross wavelet spectrum of vertical wind and particle number from an EC station on 21 June 2015 (a). Colours indicate positive and negative contributions of different timescales to the particle flux over the day. During sporadic new particle formation (NPF), deposition was observed (red), in contrast to emission during non-event sections (blue). The hatched regions at both ends show the cone of influence, where edge effects influence the wavelet analysis. (b) Particle fluxes calculated by standard eddy covariance procedures for 30 min intervals (black dashed line), and reconstructed from wavelet analysis for $1 \mathrm{~min}$ intervals (grey). The $30 \mathrm{~min}$ EC particle fluxes show significant deposition affected by NPF at 12:30 UTC.
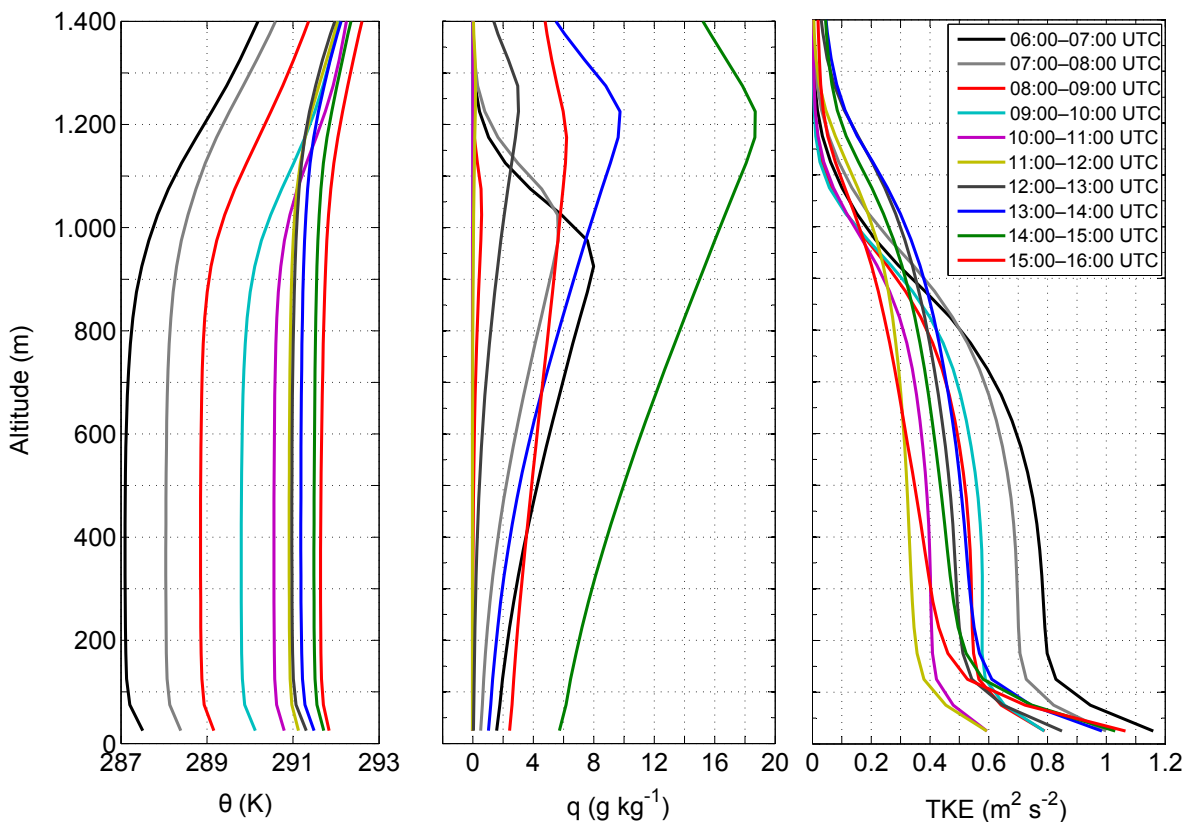

Figure 8. Potential temperature $\theta$, water vapour mixing ratio $q$ and turbulent kinetic energy TKE depending on the altitude, estimated with the LES model in $1 \mathrm{~h}$ time intervals starting from 06:00 until 16:00 UTC during the MelCol experiment on 21 June 2015. Highest values of $q$ were estimated between the height of 950 and $1210 \mathrm{~m}$ close to the inversion layer and appeared before sporadic NPF occurrence at ground. 

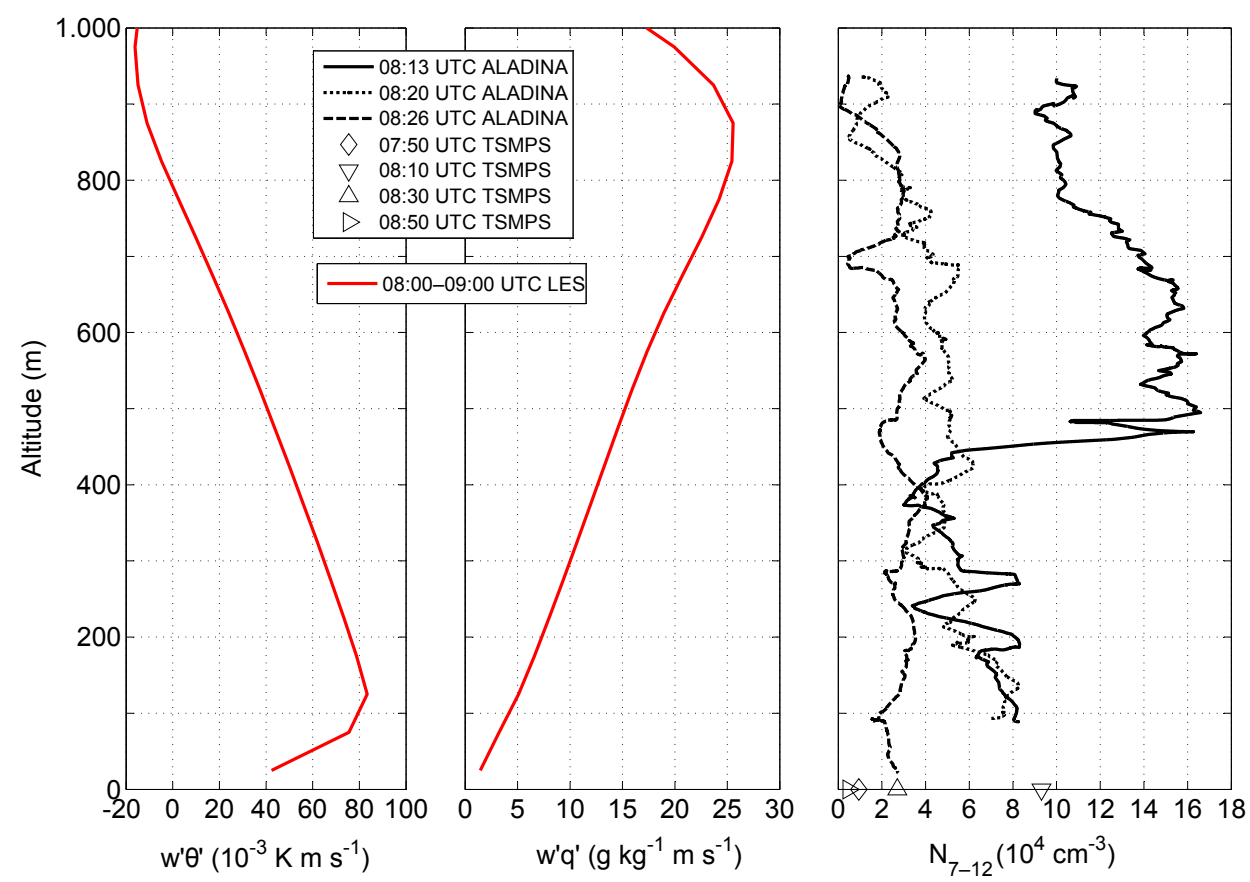

Figure 9. Vertical profiles of sensible heat flux $w^{\prime} \theta^{\prime}$ in $\mathrm{K} \mathrm{m} \mathrm{s}^{-1}$ and latent heat flux $w^{\prime} q^{\prime}$ in $\mathrm{g} \mathrm{kg}^{-1} \mathrm{~m} \mathrm{~s}^{-1}$ obtained by LES output in the interval of 08:00-09:00 UTC (red lines). Besides, three vertical profiles of freshly formed boundary layer aerosol in the particle diameter between 7 and $12 \mathrm{~nm}\left(N_{7-12}\right)$ measured with the CPCs on the UAS ALADINA at 08:13 (solid line), 08:20 (dotted line) and 08:26 UTC (dashed line) are compared with the aerosol particle number concentration derived by TSMPS in the diameter range of 7 and $12 \mathrm{~nm}$ at $07: 50$, 08:10, 08:30 and 08:50 UTC. All data were derived during the MelCol experiment on 21 June 2015.
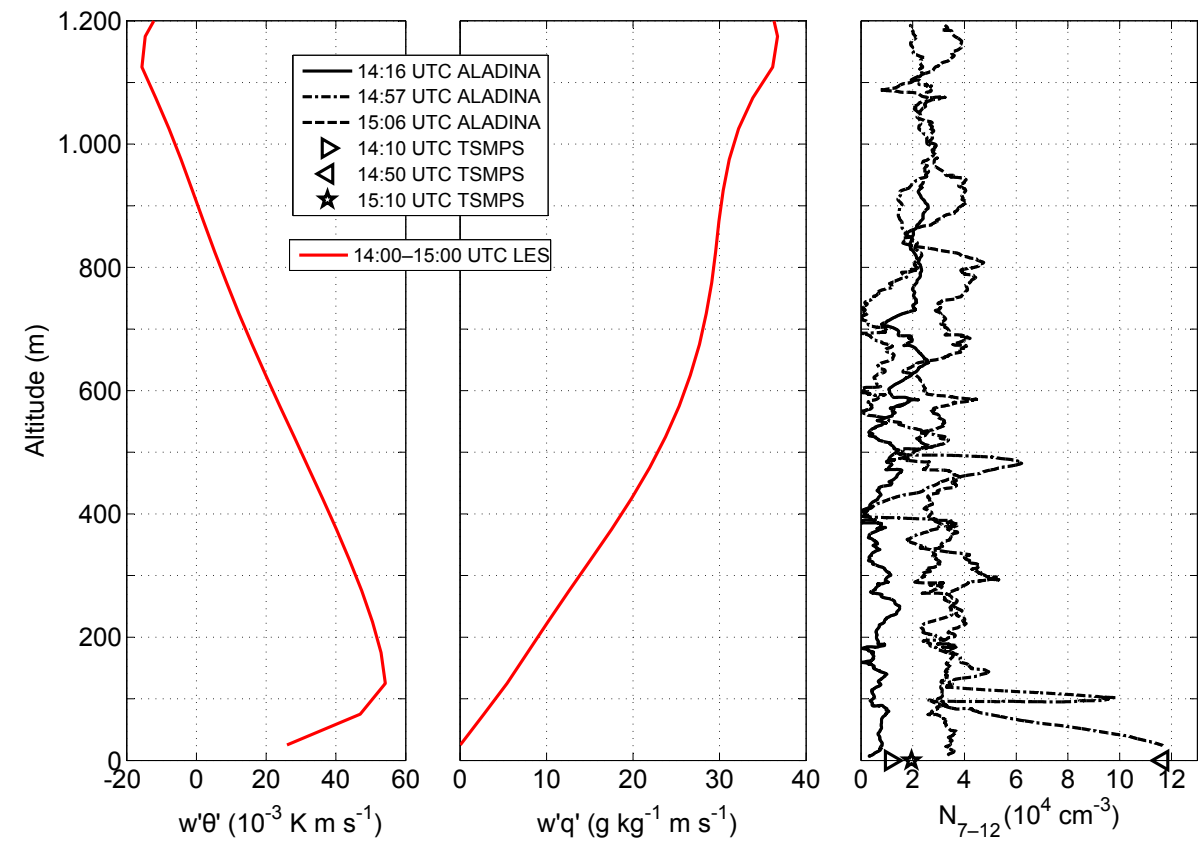

Figure 10. Vertical profiles of sensible heat flux $w^{\prime} \theta^{\prime}$ and latent heat flux $w^{\prime} q^{\prime}$ obtained by LES output in the interval of 14:00-15:00 UTC (red lines). Besides, three vertical profiles of freshly formed boundary aerosol in the particle diameter between 7 and $12 \mathrm{~nm}\left(N_{7-12}\right)$ measured with the CPCs on the UAS ALADINA at 14:16 UTC (solid line), 14:57 (dotted line) and 15:06 UTC (dashed line) are compared with the aerosol particle number concentration derived by TSMPS in the diameter range of 7 and $12 \mathrm{~nm}$ at 14:10, 14:50 and 15:10 UTC. All data were derived during the MelCol experiment on 21 June 2015. 
tration of $4.2 \times 10^{4} \mathrm{~cm}^{-3}$. The vertical distribution of latent heat flux showed a continuously increase with a maximum of $38 \mathrm{~g} \mathrm{~kg}^{-1} \mathrm{~m} \mathrm{~s}^{-1}$ at $1150 \mathrm{~m}$.

Again, airborne data were consistent with ground observations by TSMPS; however, the temporal evolution of vertical profiles led to the assumption that NPF occurred at ground instead of aloft. However, fast mixing was observed and at the same time an increase in the aerosol particle number concentration in the vertical pattern.

\section{Concluding remarks}

Freshly formed boundary layer aerosol was measured with the ALADINA unmanned aerial system (UAS) under cloudy conditions at the research site of TROPOS in Melpitz. In total, 105 airborne measurements with a total flight duration of $53 \mathrm{~h}$ were performed on 23 measurement days since October 2013. During six of these measurement days, new particle formation (NPF) events were observed under non-favourable conditions (e.g. low concentrations of precursor gases, dense cloud coverage) near the inversion layer and were mixed vertically induced by atmospheric boundary layer (ABL) dynamic processes. However, only sporadic appearances of small particles were detected at ground and might not have been taken into account as an NPF event. This study focused on two different measurement days: (i) on 4 April 2014 by north-easterly wind and (ii) on 21 June 2015 under south-westerly wind. During the first case, a maximum of $N_{5-10}=3.5 \times 10^{3} \mathrm{~cm}^{-3}$ was detected above a capping inversion layer at the height of around $400 \mathrm{~m}$ a.g.l. in connection with a decline of $N_{390}$ from 230 to $130 \mathrm{~cm}^{-3}$. High moisture with a maximum of $q=18.5 \mathrm{~g} \mathrm{~kg}^{-1}$ was present above the inversion layer. The layer of the freshly formed aerosol spread out vertically in the boundary layer with a maximum of $3.8 \times 10^{4} \mathrm{~cm}^{-3}$ for particles with a diameter size exceeding $5 \mathrm{~nm}$. However, altered clusters (particle size between 30 and $50 \mathrm{~nm}$ ) were measured at ground with a TSMPS during the process in relation to an increase in $\mathrm{NO}_{x}$ so that anthropogenic emissions might have favoured the NPF occurrence in the residual layer as well. The research site was influenced by NE wind, so that high emissions of anthropogenic sources were expected from eastern Europe, as stated by Junkermann et al. (2016), who found NPF events in connection with local plumes over eastern Germany. However, changes in wind direction were not seen in wind measurements with ALADINA. The study of Bianchi et al. (2016) at the Jungfraujoch site in the free troposphere might support the present observations that NPF occurs under more conditions as expected so far; NPF was not only related to sulphuric acid formation, which is a common identifier for nucleation, but instead NPF depended on high concentrations of organic compounds from anthropogenic origin. On 21 June 2015, the site was influenced by a low-pressure system with stratocumulus clouds and SW wind. At 08:13 UTC, ALADINA ob- served a maximum of $N_{7-12}=1.6 \times 10^{5} \mathrm{~cm}^{-3}$ at the altitude of $420 \mathrm{~m}$ a.g.l. and decreased while descending. Within $17 \mathrm{~min}$, the newly formed aerosol load was mixed vertically or disappeared as confirmed by pronounced fluxes of sensible heat, taken from an LES model output, with a maximum of $w^{\prime} \theta^{\prime}=81 \times 10^{-3} \mathrm{~K} \mathrm{~m} \mathrm{~s}^{-1}$ in the lowermost $160 \mathrm{~m}$. The temporal evolution showed that the formation observed at ground originated from the ABL and was mixed vertically and transported downwards to the surface, as previously observed in Platis et al. (2016) under clear-sky conditions. Another sporadic occurrence of ultrafine particles was captured with the UAS in the afternoon between 14:10 and 15:10 UTC and showed that the formation process occurred at ground and was rapidly mixed in the vertical distribution initiated by a significant increase in $w^{\prime} \theta^{\prime}=58 \times 10^{-3} \mathrm{~K} \mathrm{~m} \mathrm{~s}^{-1}$ in the lowermost $150 \mathrm{~m}$. Besides, the UAS observations were consistent with TSMPS data in the same diameter range of $N_{7-12}$, clarifying the reliability of the system. The $\mathrm{CO}_{2}$ and particle fluxes indicated large fluctuations upwards and downwards, depending on the variation in ABL clouds that coincide with sporadic NPF at ground. For instance, high deposition with a maximum particle flux of $-26 \times 10^{6} \mathrm{~m}^{-2} \mathrm{~s}^{-1}$ was measured along with a particle burst in the size of 10 and $40 \mathrm{~nm}$.

To conclude, high humidity and pronounced turbulent fluxes were clearly the dominant factor in the ABL to favour NPF, even if conditions were generally not favourable. The authors' hypothesis is that the events observed here are locally restricted and not homogeneous over larger regions. This is because the clouds, in particular, create inhomogeneities in the intensity of solar radiation reaching the ground. On the other hand, clouds and their surrounding regions, as well as the inversion layer, are influenced by large gradients in various parameters. These gradients in combination with local turbulence may create strong non-linearities being a favourable environment for NPF, which has been discussed theoretically by Easter and Peters (1994) and shown in situ by Wehner et al. (2015). The dynamics of such an event being locally restricted to small regions are completely different and can not be explained by characteristics of a large-scale event and relation to air mass. The small NPF events may occur suddenly, followed by fast growth but also fast dilution, confirmed by sporadic clusters in TSMPS data. To summarize, the observations lead to the assumption that occurrence of NPF within the boundary layer are underestimated if only ground observations are available and a more profound understanding of the vertical structure of the $\mathrm{ABL}$ is necessary in order to characterize NPF events.

Code and data availability. At the current state, the data sets are not publicly accessible, as analyses and further publications of the campaign MelCol 2015 are still in progress by other participants, but will be delivered upon request. The open-access data will be provided in the future, e.g. in PANGAEA. To get access to the source code and additional scripts for pre- and postprocessing of 
the LES model, registration at the TROPOS Git hosting website http://gitorious.tropos.de/ (last access: 11 June 2018) is mandatory. Additional information can be found at the ASAM webpage (http://asam.tropos.de, last access: 11 June 2018).

Competing interests. The authors declare that they have no conflict of interest.

Acknowledgements. This work is funded by the German Research Foundation (DFG) under the project numbers LA 2907/5-1, WI 1449/22-1, BA 1988/14-1 and LA 2907/5-2, WI 1449/22-2, BA 1988/14-2. The authors thank Lutz Bretschneider, Nico Weil and Simon Nieschke for their technical support and for performance as good safety pilots. We acknowledge Norman Wildmann, Henning Busse and Andreas Scholtz for active assistance with the ALADINA system. Thanks to Huguette Djoumsap Takam, Mareike Decker and Maike Siekmann who were studying different formation events in Melpitz and have brought forward this study. A special thanks to the whole TROPOS team and MelCol participants, especially Ralf Käthner, Achim Grüner and Gerald Spindler for the valuable support on site and for offering access to Melpitz and TROPOS data. The authors thank Armin Raabe of the Institute of Meteorology from the University Leipzig for providing turbulence data at ground. The simulations were performed at the Center for Information Services and High Performance Computing (ZIH) at TU Dresden. The authors acknowledge the two anonymous referees and Wolfgang Junkermann for detailed proof reading of the manuscript and their constructive comments.

Edited by: Veli-Matti Kerminen

Reviewed by: two anonymous referees

\section{References}

Althausen, D., Engelmann, R., Baars, H., Heese, B., Ansmann, A., Müller, D., and Komppula, M.: Portable Raman Lidar PollyXT for automated profiling of aerosol backscatter, extinction, and depolarization, J. Atmos. Ocean. Tech., 26, 2366-2378, https://doi.org/10.1175/2009JTECHA1304.1, 2009.

Altstädter, B., Platis, A., Wehner, B., Scholtz, A., Wildmann, N., Hermann, M., Käthner, R., Baars, H., Bange, J., and Lampert, A.: ALADINA - an unmanned research aircraft for observing vertical and horizontal distributions of ultrafine particles within the atmospheric boundary layer, Atmos. Meas. Tech., 8, 16271639, https://doi.org/10.5194/amt-8-1627-2015, 2015.

Baars, H., Seifert, P., Engelmann, R., and Wandinger, U.: Target categorization of aerosol and clouds by continuous multiwavelength-polarization lidar measurements, Atmos. Meas. Tech., 10, 3175-3201, https://doi.org/10.5194/amt-103175-2017, 2017

Baldauf, M., Seifert, A., Förstner, J., Majewski, D., Raschendorfer, M., and Reinhardt, T.: Operational convective-scale numerical weather prediction with the COSMO model: description and sensitivities, Mon. Weather Rev., 139, 3887-3905, https://doi.org/10.1175/MWR-D-10-05013.1, 2011.
Bärfuss, K., Pätzold, F., Altstädter, B., Kathe, E., Nowak, S, Bretschneider, L., Bestmann, U., and Lampert, A.: New Setup of the UAS ALADINA for Measuring Boundary Layer Properties, Atmospheric Particles and Solar Radiation, Atmosphere, 9, 1-21, https://doi.org/10.3390/atmos9010028, 2018.

Bianchi, F., Tröstl, J., Junninen, H., Frege, C., Henne, S., Hoyle, C. R., Molteni, U., Herrmann, E., Adamov, A., Bukowiecki, N., Chen, X., Duplissy, J., Gysel, M., Hutterli, M., Kangasluoma, J., Kontkanen, J., Kürten, A., Manninen, H. E., Münch, S., Peräkylä, O., Petäjä, T., Rondo, L., Williamson, C., Weingartner, E., Curtius, J., Worsnop, D. R., Kulmala, M., Dommen, J., and Baltensperger, U.: New particle formation in the free troposphere: A question of chemistry and timing, Science, 352, 6289, 11091112, https://doi.org/10.1126/science.aad5456, 2016.

Bigg, E. K.: A mechanism for the formation of new particles in the atmosphere, Atmos. Res., 43, 129-137, https://doi.org/10.1016/S0169-8095(96)00020-8, 1997.

Birmili, W., Berresheim, H., Plass-Dülmer, C., Elste, T., Gilge, S., Wiedensohler, A., and Uhrner, U.: The Hohenpeissenberg aerosol formation experiment (HAFEX): a long-term study including size-resolved aerosol, $\mathrm{H}_{2} \mathrm{SO}_{4}, \mathrm{OH}$, and monoterpenes measurements, Atmos. Chem. Phys., 3, 361-376, https://doi.org/10.5194/acp-3-361-2003, 2003.

Boy, M., Rannik, Ü., Lehtinen, K. E. J., Tarvainen, V., Hakola, H., and Kulmala, M.: Nucleation events in the continental boundary layer: Long-term statistical analyses of aerosol relevant characteristics, J. Geophys. Res., 108, 4667, https://doi.org/10.1029/2003JD003838, 2003.

Boy, M., Hellmuth, O., Korhonen, H., Nilsson, E. D., ReVelle, D., Turnipseed, A., Arnold, F., and Kulmala, M.: MALTE - model to predict new aerosol formation in the lower troposphere, Atmos. Chem. Phys., 6, 4499-4517, https://doi.org/10.5194/acp-6-44992006, 2006.

Buzorius, G., Rannik, Ü., Nilsson, D., and Kulmala, M.: Vertical fluxes and micrometeorology during aerosol particle formation events, Tellus B, 53, 394-405, https://doi.org/10.3402/tellusb.v53i4.16612, 2001.

Deardorff, J. W.: Numerical Investigation of Neutral and Unstable Boundary Layers, J. Atmos. Sci., 29, 91-115, 1972.

Doms, G., Förstner, J., Heise, E., Herzog, H.-J., Mironov, D., Raschendorfer, M., Reinhardt, T., Ritter, B., Schrodin, R., Schulz, J.-P., and Vogel, G.: A Description of the Nonhydrostatic Regional COSMO Model, Deutscher Wetterdienst, 2011.

Easter, R. C. and Peters, L. K.: Binary homogeneous nucleation: Temperature and relative humidity fluctuations, nonlinearity, and aspects of new particle production in the atmosphere, J. Appl. Meteorol., 33, 775-784, https://doi.org/10.1175/15200450(1994)033<0775:BHNTAR>2.0.CO;2, 1994.

Engelmann, R., Kanitz, T., Baars, H., Heese, B., Althausen, D., Skupin, A., Wandinger, U., Komppula, M., Stachlewska, I. S., Amiridis, V., Marinou, E., Mattis, I., Linné, H., and Ansmann, A.: The automated multiwavelength Raman polarization and water-vapor lidar PollyXT: the neXT generation, Atmos. Meas. Tech., 9, 1767-1784, https://doi.org/10.5194/amt-9-1767-2016, 2016.

Engler, C., Rose, D., Wehner, B., Wiedensohler, A., Brüggemann, E., Gnauk, T., Spindler, G., Tuch, T., and Birmili, W.: Size distributions of non-volatile particle residuals $\left(D_{\mathrm{p}}<800 \mathrm{~nm}\right)$ at a rural site in Germany and relation to air mass origin, Atmos. 
Chem. Phys., 7, 5785-5802, https://doi.org/10.5194/acp-7-57852007, 2007.

Größ, J., Hamed, A., Sonntag, A., Spindler, G., Manninen, H. E., Nieminen, T., Kulmala, M., Hõrrak, U., Plass-Dülmer, C., Wiedensohler, A., and Birmili, W.: Atmospheric new particle formation at the research station Melpitz, Germany: connection with gaseous precursors and meteorological parameters, Atmos. Chem. Phys., 18, 1835-1861, https://doi.org/10.5194/acp18-1835-2018, 2018.

Hamed, A., Birmili, W., Joutsensaari, J., Mikkonen, S., Asmi, A., Wehner, B., Spindler, G., Jaatinen, A., Wiedensohler, A., Korhonen, H., Lehtinen, K. E. J., and Laaksonen, A.: Changes in the production rate of secondary aerosol particles in Central Europe in view of decreasing $\mathrm{SO}_{2}$ emissions between 1996 and 2006, Atmos. Chem. Phys., 10, 1071-1091, https://doi.org/10.5194/acp-10-1071-2010, 2010.

Hamburger, T., McMeeking, G., Minikin, A., Birmili, W., Dall'Osto, M., O’Dowd, C. D., Flentje, H., Henzing, B., Junninen, H., Kristensson, A., de Leeuw, G., Stohl, A., Burkhart, J. F., Coe, H., Krejci, R., and Petzold, A.: Overview of the synoptic and pollution situation over Europe during the EUCAARILONGREX field campaign, Atmos. Chem. Phys., 11, 10651082, https://doi.org/10.5194/acp-11-1065-2011, 2011.

Hamburger, T., McMeeking, G., Minikin, A., Petzold, A., Coe, H., and Krejci, R.: Airborne observations of aerosol microphysical properties and particle ageing processes in the troposphere above Europe, Atmos. Chem. Phys., 12, 11533-11554, https://doi.org/10.5194/acp-12-11533-2012, 2012.

Heese, B., Flentje, H., Althausen, D., Ansmann, A., and Frey, S.: Ceilometer lidar comparison: backscatter coefficient retrieval and signal-to-noise ratio determination, Atmos. Meas. Tech., 3, 1763-1770, https://doi.org/10.5194/amt-3-1763-2010, 2010.

Heinze, R., Moseley, C., Böske, L. N., Muppa, S. K., Maurer, V., Raasch, S., and Stevens, B.: Evaluation of large-eddy simulations forced with mesoscale model output for a multi-week period during a measurement campaign, Atmos. Chem. Phys., 17, 7083-7109, https://doi.org/10.5194/acp-17-7083-2017, 2017.

Heintzenberg, J., Wiedensohler, A., Conrath, T., Kütz, S., and Dubois, R.: Modification of a commercial condensation particle counter for boundary layer balloon-borne aerosol studies, J. Aerosol Sci., 29, S707-S708, https://doi.org/10.1016/S00218502(98)90536-5, 1999.

Heintzenberg, J., Wehner, B., and Birmili, W.: How to find bananas in the atmospheric aerosol: new approach for analyzing atmospheric nucleation and growth events, Tellus B, 59, 273-282, https://doi.org/10.1111/j.1600-0889.2007.00249.x, 2007.

IPCC: Climate Change 2007: The Physical Science Basis, in: Contribution of Working Group I to the Fourth Assessment Report of the Intergovernmental Panel on Climate Change, edited by: Solomon, S., Qin, D., Manning, M., Chen, Z., Marquis, M., Averyt, K. B., Tignor, M., and Miller, H. L.: Cambridge University Press, Cambridge and New York, 996 pp., 2007.

Jähn, M., Knoth, O., König, M., and Vogelsberg, U.: ASAM v2.7: a compressible atmospheric model with a Cartesian cut cell approach, Geosci. Model Dev., 8, 317-340, https://doi.org/10.5194/gmd-8-317-2015, 2015.

Jähn, M., Muñoz-Esparza, D., Chouza, F., Reitebuch, O., Knoth, O., Haarig, M., and Ansmann, A.: Investigations of boundary layer structure, cloud characteristics and vertical mixing of aerosols at
Barbados with large eddy simulations, Atmos. Chem. Phys., 16, 651-674, https://doi.org/10.5194/acp-16-651-2016, 2016.

Jimínez, P. A., Dudhia, J., Gonzalez-Rouco, J. F., Navarro, J., Montavez, J. P., and Garcia-Bustamante, E.: A Revised Scheme for the WRF Surface Layer Formulation, Mon. Weather Rev., 140, 898-918, 2012.

Junkermann, W., Vogel, B., and Bangert, M.: Ultrafine particles over Germany - an aerial survey, Tellus B, 68, 29250, https://doi.org/10.3402/tellusb.v68.29250, 2016.

Keil, A. and Wendisch, M.: Bursts of Aitken mode and ultrafine particles observed at the top of continental boundary layer clouds, Aerosol Sci., 32, 649-660, https://doi.org/10.1016/S00218502(00)00102-6, 2001.

Kerminen, V.-M., Lihavainen, H., Komppula, M., Viisanen, Y., and Kulmala, M.: Direct observational evidence linking atmospheric aerosol formation and cloud droplet activation, Geophys. Res. Lett., 32, L14803, https://doi.org/10.1029/2005GL023130, 2005.

Kulmala, M., Vehkamäki, H., Petäjä, T., Dal Maso, M., Lauri, A., Kerminen, V.-M., Birmili, W., and McMurry, P. H.: Formation and growth rates of ultrafine atmospheric particles: a review of observations, Aerosol Sci., 35, 143-176, https://doi.org/10.1016/j.jaerosci.2003.10.003, 2004.

Manninen, H. E., Nieminen, T., Asmi, E., Gagné, S., Häkkinen, S., Lehtipalo, K., Aalto, P., Vana, M., Mirme, A., Mirme, S., Hõrrak, U., Plass-Dülmer, C., Stange, G., Kiss, G., Hoffer, A., Törő, N., Moerman, M., Henzing, B., de Leeuw, G., Brinkenberg, M., Kouvarakis, G. N., Bougiatioti, A., Mihalopoulos, N., O'Dowd, C. D., Ceburnis, D., Arneth, A., Svenningsson, B., Swietlicki, E., Tarozzi, L., Decesari, S., Facchini, M. C., Birmili, W., Sonntag, A., Wiedensohler, A., Boulon, J., Sellegri, K., Laj, P., Gysel, M., Bukowiecki, N., Weingartner, E., Wehrle, G., Laaksonen, A., Hamed, A., Joutsensaari, J., Petäjä, T., Kerminen, V.-M., and Kulmala, M.: EUCAARI ion spectrometer measurements at 12 European sites - analysis of new particle formation events, Atmos. Chem. Phys., 10, 7907-7927, https://doi.org/10.5194/acp10-7907-2010, 2010.

Moeng, C.-H. and Wyngaard, J. C.: Evaluation of Turbulent Transport and Dissipation Closures in Second-Order Modeling, J. Atmos. Sci., 46, 2311-2330, 1989.

Nilsson, E. D., Rannik, Ü., Kulmala, M., Buzorius, G., and O'Dowd, C. D.: Effects of continental boundary layer evolution, convection, turbulence and entrainment, on aerosol formation, Tellus, 53, 441-461, https://doi.org/10.1034/j.16000889.2001.530409.x, 2001.

O’Dowd, C. D., Yoon, Y. J., Junkermann, W., Aalto, P., Kulmala, M., Lihavainen, H., and Viisanen, Y.: Airborne measurements of nucleation mode particles II: boreal forest nucleation events, Atmos. Chem. Phys., 9, 937-944, https://doi.org/10.5194/acp-9937-2009, 2009.

Pal, S. R., W. Steinbach, and Carswell, A. I.: Automated method for lidar determination of cloud-base height and vertical extent, Appl. Optics, 31, 1488-1494, https://doi.org/10.1364/AO.31.001488, 1992.

Platis, A., Altstädter, B., Wehner, B., Wildmann, N., Lampert. A., Hermann, M., Birmili, W., and Bange, J.: An observational case study on the influence of atmospheric boundary layer dynamics on the new particle formation, Bound.-Lay. Meteorol., 158, 6792, https://doi.org/10.1007/s10546-015-0084-y, 2016. 
Putaud, J.-P., Raes, F., Van Dingenen, R., Brüggemann, E., Facchini, M.-C., Decesari, S., Fuzzi, S., Gehrig, R., Hüglin, C., Laj, P., Lorbeer, G., Maenhaut, W., Mihalopoulos, N., Müller, K., Querol, X., Rodriguez, S., Schneider, J., Spindler, G., Ten Brink, H., Tørseth, K., and Wiedensohler, A.: A European aerosol phenomenology - 2: chemical characteristics of particulate matter at kerbside, urban, rural and background sites in Europe, Atmos. Environ., 38, 2579-2595, https://doi.org/10.1016/j.atmosenv.2004.01.041, 2004.

Seifert, A. and Beheng, K. D.: A two-moment cloud microphysics parameterization for mixed-phase clouds, Meteorol. Atmos. Phys., 92, 45-66, 2006.

Siebert, H., Stratmann, F., and Wehner, B.: First observations of increased ultrafine particle number concentrations near the inversion of a continental planetary boundary layer and its relation to ground-based measurements, Geophys. Res. Lett., 31, L09102, https://doi.org/10.1029/2003GL019086, 2004.

Spindler, G., Teichmann, U., and Sutton, M. A.: Ammonia dry deposition over grassland - micrometeorological flux-gradient measurements and bi-directional flux calculations using an inferential model, Q. J. Roy. Meteor. Soc., 127, 795-814, https://doi.org/10.1002/qj.49712757305, 2001.

Spindler, G., Müller, K., Brüggemann, E., Gnauk, T., and Herrmann, H.: Long-term-size-segregated characterization of $\mathrm{PM}_{10}$, $\mathrm{PM}_{2.5}$ and $\mathrm{PM}_{1}$ at the IfT reseach station Melpitz downwind of Leipzig (Germany), Atmos. Environ., 38, 5333-5347, https://doi.org/10.1016/j.atmosenv.2003.12.047, 2004.

Spindler, G., Gnauk, T., Grüner, A., Iinuma, Y., Müller, K., Scheinhardt, S., and Herrmann, H.: Size-segregated characterization of PM10 at the EMEP site Melpitz (Germany) using a fivestage impactor: a six year study, J. Atmos. Chem., 69, 127-157, https://doi.org/10.1007/s10874-012-9233-6, 2012.

Wehner, B., Siebert, H., Ansmann, A., Ditas, F., Seifert, P., Stratmann, F., Wiedensohler, A., Apituley, A., Shaw, R. A., Manninen, H. E., and Kulmala, M.: Observations of turbulenceinduced new particle formation in the residual layer, Atmos. Chem. Phys., 10, 4319-4330, https://doi.org/10.5194/acp-104319-2010, 2010.

Wehner, B., Werner, F., Ditas, F., Shaw, R. A., Kulmala, M., and Siebert, H.: Observations of new particle formation in enhanced UV irradiance zones near cumulus clouds, Atmos. Chem. Phys., 15, 11701-11711, https://doi.org/10.5194/acp-15-117012015, 2015.

Wiedensohler, A., Covert, D. S., Swietlicki, E., Aalto, P., Heintzenberg, J., and Leck, C.: Occurrence of an ultrafine particle mode less than $20 \mathrm{~nm}$ diameter in the marine boundary layer during Arctic summer and autumn, Tellus, 48, 213-222, https://doi.org/10.1034/j.1600-0889.1996.t01-1-00006.x, 1996.
Wiedensohler, A., Hansson, H.-C., Orsini, D., Wendisch, M., Wagner, F., Bower, K. N., Chourlarton, T. W., Wells, M., Parkin, M., Acker, K., Wieprecht, W., Facchini, M. C., Lind, J. A., Fuzzi, S., Arends, B. G., and Kulmala, M.: Night-time formation and occurrence of new particles associated with orographic clouds, Atmos. Environ., 31, 2545-2559, https://doi.org/10.1016/S13522310(96)00299-3, 1997.

Wiedensohler, A., Birmili, W., Nowak, A., Sonntag, A., Weinhold, K., Merkel, M., Wehner, B., Tuch, T., Pfeifer, S., Fiebig, M., Fjäraa, A. M., Asmi, E., Sellegri, K., Depuy, R., Venzac, H., Villani, P., Laj, P., Aalto, P., Ogren, J. A., Swietlicki, E., Williams, P., Roldin, P., Quincey, P., Hüglin, C., Fierz-Schmidhauser, R., Gysel, M., Weingartner, E., Riccobono, F., Santos, S., Grüning, C., Faloon, K., Beddows, D., Harrison, R., Monahan, C., Jennings, S. G., O’Dowd, C. D., Marinoni, A., Horn, H.-G., Keck, L., Jiang, J., Scheckman, J., McMurry, P. H., Deng, Z., Zhao, C. S., Moerman, M., Henzing, B., de Leeuw, G., Löschau, G., and Bastian, S.: Mobility particle size spectrometers: harmonization of technical standards and data structure to facilitate high quality long-term observations of atmospheric particle number size distributions, Atmos. Meas. Tech., 5, 657-685, https://doi.org/10.5194/amt-5-657-2012, 2012.

Wiegner, M. and Geiß, A.: Aerosol profiling with the Jenoptik ceilometer CHM15kx, Atmos. Meas. Tech., 5, 1953-1964, https://doi.org/10.5194/amt-5-1953-2012, 2012.

Wildmann, N., Mauz, M., and Bange, J.: Two fast temperature sensors for probing of the atmospheric boundary layer using small remotely piloted aircraft (RPA), Atmos. Meas. Tech., 6, 8, 21012113, https://doi.org/10.5194/amt-6-2101-2013, 2013.

Wildmann, N., Ravi, S., and Bange, J.: Towards higher accuracy and better frequency response with standard multi-hole probes in turbulence measurement with remotely piloted aircraft (RPA), Atmos. Meas. Tech., 7, 1027-1041, https://doi.org/10.5194/amt7-1027-2014, 2014a.

Wildmann, N., Kaufmann, F., and Bange, J.: An inverse-modelling approach for frequency response correction of capacitive humidity sensors in ABL research with small remotely piloted aircraft (RPA), Atmos. Meas. Tech., 7, 3059-3069, https://doi.org/10.5194/amt-7-3059-2014, 2014b. 